NBER WORKING PAPER SERIES

\author{
HOW YOU PAY AFFECTS HOW YOU DO: \\ FINANCIAL AID TYPE AND STUDENT PERFORMANCE IN COLLEGE \\ Peter Cappelli \\ Shinjae Won \\ Working Paper 22604 \\ http://www.nber.org/papers/w22604
}

\author{
NATIONAL BUREAU OF ECONOMIC RESEARCH \\ 1050 Massachusetts Avenue \\ Cambridge, MA 02138 \\ September 2016
}

Thanks to Iwan Barankay, Katherine Milkman, and Judd Kessler for helpful comments, to the National Center for Educational Statistic's site license program for access to the data, and to Wharton's Center for Human Resources for support. Data can be accessed through application to the National Center on Educational Statistics at the US department of Education. The views expressed herein are those of the author and do not necessarily reflect the views of the National Bureau of Economic Research.

NBER working papers are circulated for discussion and comment purposes. They have not been peer-reviewed or been subject to the review by the NBER Board of Directors that accompanies official NBER publications.

(C) 2016 by Peter Cappelli and Shinjae Won. All rights reserved. Short sections of text, not to exceed two paragraphs, may be quoted without explicit permission provided that full credit, including (๑) notice, is given to the source. 
How You Pay Affects How You Do: Financial Aid Type and Student Performance in College Peter Cappelli and Shinjae Won

NBER Working Paper No. 22604

September 2016

JEL No. D03,I21,I23,J38

\title{
ABSTRACT
}

Students receiving financial aid pay different amounts for equivalent education and do so in different ways: Grants, which do not have to be repaid, loans, which are paid back in the future, and work-study, pay-as-you-go. We examine the effects of need-based aid independent of study ability on student outcomes - grade point average in particular - controlling for student background and attributes they had prior to college. We also analyze grades within colleges. The results suggest that students receiving need-based grants do significantly better in college than those not receiving financial aid while those paying for college with loans perform significantly worse than students receiving other forms of aid.

\author{
Peter Cappelli \\ The Wharton School \\ Center for Human Resources \\ University of Pennsylvania \\ Philadelphia, PA 19104-6358 \\ and NBER \\ cappelli@wharton.upenn.edu \\ Shinjae Won \\ University of Illinois \\ School of Labor and Employment Relations \\ 504 East Armory Avenue \\ Champaign, IL 61820 \\ Shinjae@illinois.edu
}




\section{How You Pay Affects How You Do: Financial Aid Type and Student Performance in College}

\section{Introduction:}

College educations are now a central feature of modern economies, and financial aid has been the main policy instrument for increasing access to them. The typical question raised about financial aid is how it affects college completion. But financial aid raises other interesting questions as well that stem from the fact that students in the same college receiving the same education are paying different prices for that education. Financial aid is also delivered in very different ways, each with different requirements. The question we examine below is how getting aid, and getting it through different mechanisms, affects student outcomes in college.

The three basic forms of aid are grants, which do not have to be repaid; loans, which are repaid at a later date; and work-study, which is essentially paid in the form of student employment at the same time as receiving the education. These very different ways of paying for college may well have very different effects on student outcomes. Surprisingly, this issue has rarely been examined.

Ideas as to what those effects might look like can be found in behavioral fields. For example, grants - free money - may make students who receive it enjoy their education even more because they do not have to pay for it but take it less seriously for the same reason. The literature on gifts, on the other hand, suggests an opposite conclusion, that grants may create a need to reciprocate by working harder. Work-study programs might have the opposite effect of reminding students about the cost of their education, making it less enjoyable but also making them take it less seriously. Delaying payment, as with loans, may have effects that are somewhere in between, enjoying it more when they are in school, taking it less seriously, but then appreciating it less when they are paying for it. We examine these hypotheses below.

Studying relationships like these in a field setting is obviously challenging because individuals typically have control over how they pay for items as well as how they respond to them. Omitted variables and endogeneity are therefore substantial concerns. We have some advantages in addressing these concerns. The rich variety of information available in the data offers 
extensive controls for factors that might affect student outcomes independent of the influence of financial aid, such as academic ability before entering college and various attributes of family background. The fact that the financial aid in the period we study was not based on merit or academic ability reduces the most obvious concern about endogeneity, that more able students get aid. Standardized aid practices in that period made it difficult for students to shop for different financial aid packages across colleges. We can also examine outcomes in contexts where sorting behavior is less of an issue.

We compare situations where college education was paid by grants that did not have to be repaid, by work-study programs where one "paid” as they went to school, and by loans that had to be repaid at later dates. We then examine how these different payment arrangements affected subsequent student outcomes in college and after graduation using unique longitudinal data from the US Department of Education's Post Baccalaureate and Beyond study, which gathered data on students who graduated from four-year colleges in 1993 and then followed them over time. The estimates control for attributes of student ability before college, including aptitude test scores, as well as aspects of family background that may affect student performance. The data also allow us to examine student outcomes within the same college. We also examine the relationships using regression discontinuity and instrumental variables techniques for robustness purposes.

The most important outcome we study is academic performance in college. We assert that grades are strongly influenced by student effort, controlling for factors like basic ability, and that the motivation to work hard can be shaped by the nature of the payment arrangements described above.

We find that students receiving financial aid actually do better in school than those not receiving financial aid, despite the extensive literature showing that unmeasured attributes associated with lower income should cause them to perform less well. That result is consistent with the gift exchange idea in that students receiving grants, which do not need to be repaid, perform better than those receiving other forms of financial aid. Students who take out loans, in contrast, perform worse than those receiving other forms of financial aid. We find across specifications that student who receive grants have grades that are about 0.12 points higher on a 4.00 scale than students who do not, controlling for other attributes, about one quarter of a standard deviation. 
Students who receive student loans receive grades roughly 0.8 to 0.10 points lower than those receiving financial aid in other forms, again other things equal and across different specifications.

The tests of behavioral ideas such as mental accounting and gift exchange have grown increasingly sophisticated in their ability to address methodological concerns. We examine several behavioral ideas simultaneously in a field setting, and we do not claim that the results here provide strong tests of those ideas. Instead, we see the results as offering practical evidence concerning a very significant public policy practice and probable explanations for those outcomes that are consistent with some behavioral models.

\section{Prior Research: The College Context}

Both the antecedents and consequences of college education have been the subject of extensive study. Education has important effects on individual outcomes as well as more generally on societal outcomes such as inequality. Recent concerns about growing income inequality that is driven by college attainment have made access to college an increasingly relevant topic (see McCall 2000 for an overview).

College educations are expensive to produce, and access to them depends on having the resources needed to pay the tuition and associated expenses (see Dynarski 2002 and Hoxyby 2004 for an overview of the economic issues). Alwin (1974) early on noted that the selection effects associated with college entrance, including income, affect admissions but also overall student outcomes in important ways. Largely because of that relationship, public policy as well as the practices of individual schools over time created financial aid to expand access to college to those who otherwise did not have the ability to pay. Baker and Velez (1996) found that financial aid had substantial effects on increasing access to college among those who previously would not have attended. But the remediation was not perfect. Steelman, Carr, and Powell (1989), for example, explain how family size and birth order affects resources for college: Larger families have fewer resources per child but that also creates more opportunity for the latter children to receive need-based financial aid. Downey (1995) extends the argument about family size to student performance. 
One of the challenges in assessing the effects of need-based financial aid is that receiving it is correlated with many other factors that affect student outcomes directly, such as the socioeconomic status of the family (Buchmann and DiPrete 2006) and the demographic diversity of the student (Alon and Tienda 2007). Those factors are associated with reduced student performance. Assessing the independent effect of financial aid on student performance is therefore a fundamental empirical challenge. The first challenge, though, is to think about how financial aid should affect student performance.

\section{Research on Payments and Consumption:}

A key conceptual attribute of financial aid is that it changes not only who pays for college but how it is paid for. Financial aid shifts much and in some cases all of the costs of attending college from the student and their families to the college and typically the government. (See Solelus 2000 for evidence on how families pay for college.) Financial aid also takes different forms, as discussed in more detail below, which change how payments take place. With college loans, for example, students pay for college but do so well after graduating when presumably they have wages and salaries high enough to do so. With work-study programs, students pay as they go. Grants mean that students do not pay at all, now or in the future.

As Thaler $(1980 ; 1985)$ noted, being reminded about the costs of a purchase makes us take that purchase more seriously. The separation in time of the payment of goods and services from the purchase of them, as Prelec and Loewenstein (1998) described it, also affects the enjoyment of the consumption and the seriousness with which we take it: the unpleasant experience of paying interferes with the pleasant experience of consumption.

Uncoupling occurs when something is purchased and consumed now but paid for later, as one might see with credit card purchases or loans. Studies since Hirschman (1979) have shown that consumers spend more, ceteris paribus, when they make purchases on credit. Soman (2001) argued that we spend more using credit in part because we do not have as much of the unpleasant effect of actually paying for the purchases at the time we make them, which otherwise acts as a restraint. Soman (2001) and Soman and Lam (2002) report that when we have to pay the bill for things we consumed earlier, it is an unpleasant reminder that has a negative effect on our 
happiness. Because we have mental budgets allocated for different areas of consumption, when we pay the bill for last month's use, it makes us feel that our phone budget is depleted at the point when we are paying. We are less likely to spend more on phone calls at that point when we are paying for last month’s calls.

The implications of these arguments for the financial aid arrangements described above are reasonably straight-forward. When we receive education through grants, it is essentially free money, and we might enjoy it more but take it less seriously as a result; with work-study, we are reminded of the cost as we consume it and take it more seriously but enjoy it less; when we use loans to pay for it after the fact, we might take it less seriously than if we were paying for it and enjoy it more but report less enjoyment in the future when we are repaying the loan.

There are alternative explanations to the free money account associated with receiving a grant, however. The notion of gift exchanges suggests that something of value for free - a gift - may create a sense of obligation to the giver that may make one feel uncomfortable, at least until the obligation has been discharged. Evidence for this process ranges from consumer marketing campaigns (Bagozzi 1974), where retailers create an obligation among potential customers, to organ donors and transplants (Sque and Payne 1994), where the recipients of the organs feel an obligation to the organ donors that they cannot reciprocate. Research in economics on this point is extensive, including a series of studies by Fehr and colleagues (e.g. Fehr, Kirchsteiger, and Riedl (1993) and Fehr, Kirchler, Weichbold, and Gchter (1998)) who pioneered such experiments, Hannan, Kagel, and Moser (2002) explore how differences in context and the attributes of subjects affect reciprocity responses, Maximiano, Sloof, and Sonnemans (2007), shows that gift exchanges can operate with groups.

As Charness, Frechetter, and Kagel (2004) find, gift exchange outcomes in laboratory settings can be reasonably sensitive to differences in context. That notion makes field research outside laboratory contexts especially important for external validity. Field studies of gift exchange have been more limited. ${ }^{2}$

\footnotetext{
${ }^{2}$ Fehr, Goette, and Zehnder (2009) provide an extensive overview of both the experimental and field research on research related to fairness in labor markets, of which gift exchange studies are one part. In related research, Lee and Rupp (2007) find that involuntary wage cuts, which could be interpreted as something like a negative gift, are
} 
In the financial aid context, students who receive financial aid in the form of a grant, which does not need to be repaid, may well perceive it as a gift, especially knowing that they would be extremely unlikely to attend college without it. If so, students may also feel an obligation to reciprocate and may do so by working harder in their coursework. Another way to discharge the obligation might be to become involved in activities that support the institution that is giving them their education and its mission. DesJardin et al (2002) speculated that this may be the case when receiving some forms of financial aid. Meer and Rosen (2012) provide some evidence for this with respect to alumni giving where students who received aid that had to be paid back in the form of loans were less likely to donate later to their alma mater than those who either did not receive financial aid or had it in forms other than loans.

An alternative to the mental accounting interpretation with respect to enjoyment is the concept of rationalization, where individuals make sense of their choices after the fact in ways that reduce the cognitive dissonance that those choices might otherwise produce. ${ }^{3}$ In a typical example, individuals who might objectively conclude that they have overpaid for something and experience discomfort from that decision could rationalize away the discomfort by persuading themselves that the item was more valuable or more worthwhile than objectively it was. Recent studies of rationalization range from individuals who make sense of their decision to use tanning beds (Banergee, Hay, and Green 2013) to tourists who rationalize away the risk of traveling in areas where terrorists operate (Fuchs, Uriely, Reichel, and Maoz 2013). In perhaps the closest context to the study here, Kay, Jimenez, and Jost (2002) find that students rationalized the need for tuition increases over which they had no control.

Rationalization might suggest that being more aware of the cost of something we purchased, especially if it is expensive, may make us value the consumption of it more, possibly taking it more seriously as a result. In the context of financial aid, we might expect that students who are

associated with more flight delays in the airline industry. Falk (2007) finds gift exchange relationships in the field setting of charity donations, and most relevant here, Gneezy and List (2006) find these effects in the context of temporary jobs. They also find these effects diminish quickly, however, and that in terms of effect sizes, they are smaller than one might expect from spending the resources in other ways. In a field experiment, Bellemare and Shearer (2009) find that Canadian tree planter productivity increases in response to a surprise pay raise, controlling for planter fixed effects.

${ }^{3}$ The research on rationalization is voluminous, starting with Festinger (1957). There are literally thousands of articles using the notion of rationalization to explain individual perceptions of their circumstances. 
paying for their education at least in part themselves may well experience dissonance when comparing their situation to other students whose education is being paid for by parents or through grants. If so, rationalization might well be expected as a means for reducing that dissonance.

A student's willingness to pursue post-graduate education, independent of their grades, may also be affected by a unique mental accounting hypothesis, that students with loans outstanding may well feel that they have fewer resources in their mental bank account for education and be less inclined to pursue post-graduate education as a result.

We can examine the above questions by looking at relationships between the type of financial aid received and student achievement, measured by grades, and the relationships with subjective measures of satisfaction with their college experience while in college and after graduation, their extra-curricular activities in college, and their interest in attending graduate school.

Which of the above concepts best fits the relationships with financial aid is an empirical question. Whether students perceive a grant as found money and respond to it that way or as a gift that requires a payback, for example, may depend on many factors that we cannot observe, such as how the aid is presented to them by the school, how their family and peers see it, and so forth. The analyses below, therefore, are best seen as providing suggestive evidence as to which conceptual framework best fits the financial aid context as perceived by students. We make no claim that these analyses offer rigorous assessments of the above concepts, which have been studied extensively elsewhere.

\section{The Practice of Financial Aid:}

Before examining the relationships, it is important to outline the context in which financial aid took place when the data we use were collected. That begins with the notion of financial aid itself.

We can think of financial aid as assistance that lowers the price of attending college. Need-based financial aid is tailored to the financial needs of the individual student. While financial aid policies and practices in the US have varied over time, the focus here is on the policies of the late 
1980s, when the graduates we examine began college, and for four-year, bachelor degree programs, which have been the focus of both public and private policy.

The different forms of payment, as driven and supported by Federal Government policy, have remained essentially the same over time:

- Grants. This is aid that does not have to be repaid.

- Work-Study. Federal funds are provided to schools to employ eligible students in parttime campus jobs

- Loans. These are repayable after graduation. Virtually all post-secondary educational loans in this period were governed by Federal policy.

Students do not repay grants. The grants are given by the school to the student, although the funding came from the Federal Government. They could be seen as house money in the mental accounting sense or as a gift in the social exchange sense.

Work-study programs represent a "pay as you go" context where payment (in the form of work) accompanies consumption. Students participating in work-study are constantly reminded of the cost of their education because they are paying for it by working as long as they receive that aid. They may take their education more seriously but also will enjoy it less, as we would expect from the mental accounting view. Or they may experience dissonance from working more than their peers for their education, which might cause them to rationalize that their education was more important than it was for their peers. While this might also make them take their education more seriously, it would make them view the experience more positively than would their peers. The concrete attribute of work-study programs is that they take time away from academic work, making it more difficult for students to devote as much time and effort to the work as they might otherwise have done (see, e.g., Triventi 2014).

Loans represent a context where payment is delayed until after graduation, essentially paying on credit. Here the hypothesis might be similar: Compared to students who themselves are not paying for college (i.e., parents or grants are paying), students receiving loans may be reminded that they have to pay for college eventually, and this may make them both take the experience 
more seriously and enjoy it less. Compared to work-study students, though, those paying through loans have not experienced the cost yet and therefore may not take their education as seriously and may enjoy it more. Rationalization offers an alternative hypothesis for satisfaction with college after the fact: Students who pay for college through loans, especially when others around them are not paying for it, may rationalize their experience after the fact in ways that make their college experience seem more worthwhile in hindsight. They might therefore report greater value from college than either work-study students or those whose education was free to them.

The complications associated with examining these relationships empirically are considerable, as discussed below, but the context in which financial aid was delivered in the period we examine the late 1980s - helps address some of those challenges.

The modern notion of financial aid in the US begins in the 1950s at private colleges where some resources were made available to support students who otherwise could not afford to attend college. A seminal development in financial aid was the creation in 1954 of the College Scholarship Service (CSS) by 95 schools in the northeast. It borrowed a model developed first at Harvard and then used at schools in the west to determine the financial need of applicants. The CSS established the criteria to measure college students and their families' ability to contribute to their education, criteria based on family income. By 1956, most private schools that offered aid to students were using that standard model. Applicants paid a fee to the CSS, which then determined the ability of the applicant and their family to pay, and suggested to the individual college the amount of aid necessary to allow that student to enroll. The principle that financial aid should be based on need - family income - and that the determinations should be common across schools was well in place.

Public policy entered financial aid with the 1958 National Defense Education Act. It pioneered loans, backed by the government, to support low-income students. The Educational Opportunity Grants program created need-based grants for low-income students that did not need to be repaid, and the 1964 Educational Opportunity Act created work-study programs by giving schools funds for employing low-income students in on-campus jobs. A series of other acts helped cement the need-based aspect of financial aid: The 1965 Higher Education Act provided Federal Government-backed insurance for privately issued, need-based student loans, as well as 
rules governing those loans, and more need-based grants for undergrads (this program became known as Pell Grants in 1972). Legislation in the 1980s sought to ensure that financial aid was targeted only to those in financial need, and the Higher Education Amendments of 1992 mandated the use of a common formula for determining need and the associated aid, eliminating the use of the CSS's application. Some private schools continued to use a modified version of the CSS application to award their own, non-governmental aid, which was still need-based. ${ }^{4}$

The intent and effect of public policy was to increase access to post-secondary education, especially at the more expensive four-year programs, in a manner that was consistent across applicants and colleges: Students with similar need got similar financial aid. The practices of colleges went even further toward standardization, motivated first by the notion that giving access to more low-income students was a very important goal and second that the best way to do so was to target the available aid to those with the greatest need. It was not possible to use public sources of financial aid to compete for students. Perhaps more important, the idea that schools would base aid even from private sources on something other than financial need, such as merit, was anathema to the participants in the higher education system.

The phrase "need-blind admission policy" that was common during the period we study here (late 1980s and early 1990s) meant that admission decisions were made without considering the financial aid implications associated with each applicant. As late as 1993, the National Association of College Admissions Counselors reaffirmed its commitment to need-blind admissions as the only form of financial aid (Cage 1993). Our review of media stories about financial aid in the period before the mid-1990s using the EBSCO database of practitioner and academic publications found that the only articles about financial aid that was not need-blind were those reporting on individual schools whose difficult financial circumstances threatened a break with the practice. There was no serious discussion of other approaches.

The reluctance to use aid in any way other than to support financially needy students is illustrated by the creation of the Overlap Group, a collection of the wealthiest schools that would

\footnotetext{
${ }^{4}$ A number of sources describe the key legislative developments and practices in US financial aid. Among them is http://www.finaid.org/educators/history.phtml and Clotfelter (1991). Jackson (2010) identifies New Deal-related decisions that were precursors to contemporary financial aid while Chen and St. John (2011) review developments at the state and local level.
} 
have been the most able to use private aid to compete for the best students. The purpose of the Group was to ensure that students who were accepted to more than one school received identical financial aid packages from each school (see Matsen 1995), eliminating even inadvertent competition. The group operated during the period we examine here. In 1993, a consent decree following US Justice Department anti-trust investigations allowed schools to keep sharing information about the financial need of students but not on the financial aid awards they were making (Matlock 1994).

Merit-based aid, where financial assistance is based on the abilities of the applicant rather than their financial need, became a factor in financial aid only recently See Appendix A for details. We can identify those limited instances in the data (below).

A complicating factor in assessing the effects of financial aid could be whether the threat of losing financial aid motivated students receiving it to perform better. For the analysis here, the relevant requirements are those promulgated by the US Department of Education in 1983, which required that colleges ensure that students are receiving Federal financial aid are making “satisfactory progress" as defined by the standards that the College uses for students not receiving such financial aid. ${ }^{5}$ In other words, the standard for being kicked out of school was the same as the standard for losing financial aid. Students interested in remaining in college faced the same standard whether or not they received financial aid.

\section{Challenges in Examining the Effects of Financial Aid}

Perhaps the most fundamental challenge in examining the effects that need-based financial aid have on student outcomes is sample heterogeneity, that family financial attributes, which

\footnotetext{
${ }^{5}$ Colleges are allowed to maintain higher standards of satisfactory progress for students receiving Federal financial aid than for other students, although why they would want to do so is not at all obvious. Federal regulations in this period say: "Bear in mind that as a rule, the Department does not regulate schools' satisfactory progress standards" with two exceptions. The first was a minimum "C" average by the end of the second year, but there were many exceptions to that requirement. The second was that whatever maximum time the school has established for completing a degree program, students who exceed 150 percent of that time will no longer be eligible for Federal aid. Students attending college part-time are eligible for aid, however. This requirement also has many exceptions, which makes it difficult to tell whether it has any differential effect on students receiving aid. Losing aid at one school did not make students ineligible for receiving aid if they were accepted at another school. See FSA Handbook for 1996. https://ifap.ed.gov/fsahandbook/doc0262 bodyoftext.htm.
} 
determine access to aid, are also directly associated with student outcomes. The evidence that family income and attributes correlated with family income affect student performance in college is voluminous. Students from poorer families tend to attend lower-quality high schools and as a result are less prepared for college but poorer households have fewer resources for learning, parents who provide less support, and so forth. (For reviews of the evidence, see Walpole 2003, Stinebrickner and Stinebrinckner 2003, and Rouse and Barrow 2006. Delaney, Harmon, Ryan 2013 provide new examples of attributes that affect student achievement and that are difficult to measure.)

The data described below allow us to control for family financial resources and related family attributes. Unobserved attributes in this context, which no doubt are important, are likely to bias estimates of financial aid's effects downward. We consider that issue below.

The fact that students choose which colleges to apply to and then to attend may also confound any relationship with student outcomes. One of the goals of financial aid was to allow students to choose the college they want to attend based on factors other than costs. In that sense, students receiving financial aid become more like students whose families have enough financial resources to pay for college without aid. Students on financial aid may still be more costsensitive than students not on financial aid, however, and may be disproportionately drawn toward colleges that are cheaper. If so, a sorting concern begins with the fact that college grades typically measure performance relative to other students in the same institution. If so, it is easier for a given student to do well in colleges that are less selective/have less able students. If such schools are also cheaper, they may attract better quality students among those needing aid than they attract from the pool of students not needing aid.

The relationships between cost and competitiveness or selectivity are not straight-forward, though, which makes a sorting explanation less obvious. Flagship state universities like U.C. Berkeley in this period were among the cheapest programs but also the most competitive; among private colleges, the most selective schools also provide the most financial aid; if more able students sorted themselves into less selective colleges, those colleges would then by definition become more selective. Although there is evidence that differences in aid does affect the choices 
that students make to matriculate among schools where they have been accepted, the effects seem to be quite modest (Nurnberg, Schapiro, Zimmerman 2012).

Nevertheless, we consider the most likely source of any sorting, which would appear to be between private and public colleges. Our discussions with former U.S. Department of Education officials involved in financial aid in this period suggests that the level of government grants was roughly targeted to cover tuition costs at public universities. Loans and work-study programs were commonly used to offset living expenses. At private universities, loans and work-study programs, which are less desirable than grants, and family contributions likely made up the gap between grant aid and tuition costs. Public universities would therefore be more attractive to price sensitive students, and those receiving financial aid may on average be more price-sensitive than those not receiving need-based aid.

We address the concern about possible sorting across colleges with additional analyses first by controlling for objective measures of student academic ability before they apply to college and for the selectivity of the college, which may relate to how difficult it is for a given student to succeed there. Second, we analyze the results within colleges, which controls for the difficulty associated with the relative aspect of academic success. Then we examine the results within the public and private institutions separately to address the concern that students with choices between private and public schools (possibly those who are disproportionately able) may be sorting themselves into the cheaper state systems.

Selection effects may be more important for students not receiving financial aid but whose family income is close to eligibility. For them, differences in tuition cost are likely to be a major factor in choosing where to apply and which college to accept, especially in comparison to those just over the eligibility criteria and for whom financial aid outcomes may reduce the influence of tuition costs. For that reason among others, we repeat the analysis using a regression discontinuity design based on each student's Pell Grant Index, the score calculated by the Federal Government to determine eligibility for need-based aid. Finally, we use instrumental variable techniques to address general aspects of sample heterogeneity.

\section{Research on the Effects of Financial Aid:}


The research on need-based financial aid is extensive, most all of which assesses the effects on student access to higher education (who enrolls) and persistence in college (who graduates). Dresch (1975) pioneered the notion that students might respond differently to how financial aid is structured, specifically that grants have a different effect on student enrollment than does the equivalent lowering of tuition. Pascarella and Terenzini (2005) survey the literature and conclude that, overall, students receiving financial aid per se are just as likely to persist in college and to graduate as compared to those who do not received financial aid, a good outcome given that the goal of financial aid was to reduce differences between those two groups. Demming and Dynarsky's (2009) survey finds support for the idea that need-based aid increases persistence and graduation rates among participants.

In terms of recent studies in aid per se, merit-based aid has become a popular topic (e.g., Cohodes and Goodman 2013) as has state-level innovations in aid, such as those creating financial incentives to perform well (e.g., Scott-Clayton 2011). For need-based aid, Brown et al. (2012), confirms the basic result that financial aid does indeed increase the likelihood of completing college. Castleman and Long (2013) find that Florida’s program increased persistence and graduation rates,

The most extensively studied form of financial aid may be work-study programs. Stinebrickner, and Stinebrickner (2003) find a negative relationship between work-study hours and student academic performance. Pascarella and Terenzini (2005: 410) summarize speculation that workstudy programs might enhance learning when the work assignments relate to the student's studies, as opposed to simply taking time away from a student's studies. More recently, Darolia (2014) reports little overall effect of work-study participation on student grades in a national sample, Scott-Clayton and Minaya (2014) find mixed effects on student outcomes, extending Scott-Clayton (2011) earlier findings.

The effects of student loans on the experience of students in college appears to be the least studied of the components of financial aid. As Demming and Dynarsky (2009 p.8) noted, "While loans are the dominant form of federal aid today, we unfortunately know little about how they affect behavior.” 
Alon (2005) observed that some of the inconsistency in results across prior studies had to do with unexplained endogeneity and omitted variables in those studies. Specifically, those receiving aid had attributes that reduced persistence compared to students not receiving aid, but when such attributes were controlled for, the evidence suggested that aid did increase persistence.

Overall, relatively few studies examine relationships between aid and student achievement, and it is difficult to find evidence on outcomes such as student satisfaction with education. Student performance per se has been studied extensively but almost exclusively through the lens of psychology, examining attributes of the individual and assessments that could be used to predict achievement (for an example, see Schmitt et al. 2007). An important exception is the recent study by Hamilton (2013), published after our study was near completion. She asks a different but related question, whether greater financial help from parents causes students to perform worse in college. The hypothesis is not expressed in terms of mental accounting, but it is consistent with the notion that if something is free it should be undervalued. She finds support for that hypothesis, that where parents pay more, student performance is less. But the analyses control for financial aid, so the results likely apply to "pocket money" from parents above and beyond tuition, room, and board.

\section{The Data and Methods:}

We use data from the Baccalaureate \& Beyond Longitudinal Study (B\&B) conducted by the US Department of Education's National Center for Education Statistics to examine these questions. The data collected information from a nationally representative sample of students who received a bachelor's degree during the 1992-1993 academic year. Financial aid decisions for this cohort would have been made in late 1980s. The sampling frame was drawn from a survey of postsecondary institutions, the National Postsecondary Student Aid Survey, and was weighted to reflect the population of all such graduates in that year and to create a sample that was representative of all four-year college graduates. Extensive information was collected from the students about their backgrounds, their families, and their academic and related experiences before they attended college and also while in college. 
The study contacted them again in 1994,1997, and 2003, this time collecting information about their work experiences and their life. The 1992-1993 data had 11810 respondents; the 2003 resurvey contained 10440. We discuss survivor bias below. The response rate for each wave of the survey was roughly 90 percent. NCES replenished some of the sample in each wave with subjects identified in the original data collection exercise, so the number of individuals who completed all three waves was less than the number completing the survey in 2003. The information contained in the surveys is voluminous although response rates for many of the individual survey items are low. A detailed description of the sampling methodology and outcomes is provided in NCES Chapter 2 (2005). Use of the B\&B data is restricted by NCES and requires a site license.

A problem we face with this sample design is that we cannot observe how financial aid affects the decision to attend college. To the extent that student abilities are roughly correlated with family socio-economic status, financial aid may allow less able students to attend college. How that relationship actually affects student outcomes is difficult to address empirically, and relatively few prior studies do so. We consider this issue further below.

A second limitation of the data is that it is restricted to those who graduated from college during 1992 and 1993. That means we cannot observe any effects that aid might have on student outcomes through relationships with retention/dropping-out. The effects we examine, such as overall grade point averages, require college completion, but if aid alters the composition of the student cohort that graduates, then that effect on outcomes such as grades should be considered. Whether the students who would have dropped out in the absence of need-based aid are better or worse performers than equivalent students who would not have dropped out is difficult to know. Again, if we believe that student abilities and performance are related to family socio-economic background and that students from the poorest backgrounds might be the most likely to drop-out in the absence of need-based aid, then the selection effect might be expected to lower average outcomes of students with financial aid by keeping in the worst performers. Whether this relationship would be net of effects associate with selection into college is not obvious, however, and we do not have the data available to address these questions empirically. 
Examining selection effects associated with drop-outs is extremely difficult because drop-outs can return to college years later and complete their degree. The usual approach, therefore, is to measure graduation rates within a given time period, such as six-year graduation rates. The data here capture all graduates in 1992-'93, which has the advantage of including students who may have taken many years to complete their degree and not censuring those who have not graduated within a given time period. Nevertheless, the analyses here are clearly limited to students who have graduated from college, which ignores selection effects associated with admissions and with retention.

We explore the effect of different types of aid on the following variables, which are described in Table 1b. The correlations between the variables are reported in Table 1a. As the descriptive statistics indicate, grants are far and away the most common form of financial aid. As we discuss in more detail below, all students receiving any kind of need-based financial aid in this period first received a grant from the Federal Government. Those with greater need also received work-study aid and/or took out loans to pay for their education. It was not possible to get loans backed by the Federal Government or work-study funding without having a grant.

\section{TABLE 1a and TABLE 1b HERE}

Academic performance Academic performance in college is, we argue, a good assessment of effort and the seriousness with which students pursued their education when we can control for academic ability. There may be many ways in principle to judge academic performance, but in practice few are available. Grade point averages (GPA) are the most common measure and the one most likely to reflect the demands associated with the effort required across classes, e.g., attendance in some, class participation in others, and so forth. GPA is no doubt a function of ability and effort. To the extent that students with lower (higher) academic ability are on average sorted into schools with lower (higher) standards, the fact that GPA is a within-school measure may cancel out some of the ability differences. 
We also include in the analysis rank measures of the academic status of each school to help control for the fact that a given GPA at a school with more rigorous academic standards may well require more effort than the same GPA at a school with lower standards, even given differences in student ability across student bodies. GPA may also require different levels of effort depending on the courses students are taking. For robustness purposes, we also examine the GPA within standard subject majors that were calculated for the dataset by the National Center for Educational Statistics: math and humanities. Finally, we examine grades within schools for those colleges that have several students are in the database - fixed effects by school.

We also assess attitudes toward one's education, which are the focus of much of the above behavioral research. The B\&B survey asked respondents in 2003 how satisfied they were with their college experience, specifically whether the graduate considered that the effort, financial cost, and the level of effort required to earn their undergraduate degree were worthwhile, respectively. There was virtually no variance in the first and third item (almost everyone answered yes). We therefore use the second item, whether my college experience was worth the cost, as our measure. The drawback to this measure for our purposes is that because it is not asked while the respondents are in school, it is not a good measure of any coincident mental accounting effect. Precisely because it is asked later, it may capture rationalization on the part of respondents.

The student's willingness to enroll in further education in subsequent years, other things equal, may reflect satisfaction with their bachelor degree education. For students paying for their education in part through loans, those loans may have a disproportionate effect on their mental bank account for future education, testing a specific aspect of the mental accounting literature. A crucial issue in assessing the willingness to enroll outcome will be the ability to control for other factors affecting that decision.

We also examine whether students volunteer to work on programs of service while in college, another possible avenue through which reciprocity could occur. 
Independent Variables: As noted above, we consider three types of financial aid variables: grants, work-study, and loans. For each type, we created a dummy variable indicating whether the student received each of them. ${ }^{6}$

\section{Estimation:}

We removed from our sample all those reporting that they received any merit-based aid (presumably any aid based on the student's attributes), including athletic scholarships, as well as those receiving financial support from the military, in order to focus on the effects of need-based aid. $^{7}$

The data provide a range of variables on family background in addition to those that are used to determine financial aid, such as the educational level of each parent, race, and family structure, and we include those measures as control variables. We add a control for those students who are financially independent because financial aid in that case is determined by attributes of the student and not their families. We also control for demographic variables of the individual student that might be related to outcomes such as sex, age, race and marital status.

\footnotetext{
${ }^{6}$ The three categories are not mutually exclusive, however. In particular, all the students who take out loans and who participate in work-study also received some amount of grant money, but not all the students receiving grants take out loans. The experience of the students can be divided into the following categories, which are exhaustive and mutually exclusive:

(1) Those who do not receive any financial aid;

(2) Those who only receive a grant;

(3) Those who receive grant and participate in work study;

(4) Those who receive grant and take out loans;

(5) Those who receive grant, participate in work study, and take out loans. One conclusion from the above is that it is not possible to observe students who only receive loans or who only participate in work-study programs. For robustness check, we also tested the effect of each of the financial aid in a clean fashion, by restricting our sample to a pair of the above five groups for each of the type of aids. To see the effect of grant, for example, we compared (1) and (2); for work study, we compared (2) and (3); for loans, we compared (2) and (4). This approach effectively defines the comparison group so that it only differs in the specific type of aid of interest. For work-study, for example, we are observing the effect of participating in work-study net of any effects associated with receiving grants; similarly for loans. The results from this analysis is consistent with the results reported with models using the three dummy variables at the same time.

${ }^{7}$ Separate analyses for these omitted groups, available on request, show that GPA is higher, other things equal, for students receiving merit aid not counted as athletic based and lower for those receiving athletic scholarships. Whether these results reflect unmeasured ability defined broadly or are the result of the aid per se (merit awards change one's self-image while athletics takes time away from studies) is impossible to say.
} 
More important, we can identify measures of the student's academic ability before they entered college using SAT and ACT scores, which are correlated with academic achievement. Even though these two tests measure different aspects of ability - SAT in this period tested aptitude regarding reasoning and verbal abilities and ACT focused on achievement based on what is learned in school - the correlation between the two test scores is high $(0.64, \mathrm{p}<0.01)$ for the subset of students (8.17\%) who took both SAT and ACT. Controlling for ability makes it easier for us to assert that the outcomes we see on performance result from effort, and effort can be influenced strongly by the behavioral effects being tested by the hypotheses.

To control for the possibility that opportunities for student outcomes vary across colleges (i.e., the same GPA may require much more effort at one school than another), we control for school quality using U.S. News \& World Report Best Colleges rankings in 1992 from the U.S. News Magazine. It ranked 1,600 schools using indicators of the quality of the program, such as student selectivity, academic reputation, graduation and retention rates and financial resources.

Although there are certainly concerns about the validity of these rankings, it is the only one available in this period for an assessment of the many colleges in our data. We used the original data from U.S. News \& World Report in this period to create five groups of institutions based on these indicators, and we assigned the value of 1 to 5 based on the data. ${ }^{8}$ Those that were not part of this ranking system were given the value of 6 because the survey did not rank schools with very low standards. We also include tuition cost across schools as a possible measure of quality.

Because the large dataset includes many students who attended the same college - graduating the same year - we can also examine grades for students within the same college.

We test the following competing hypotheses for the effects of need-based financial aid:

H1a. Students receiving grants should perform less well in school compared to students not receiving any financial aid (i.e., where their families are paying) because there is no apparent cost to the education. This is related to the mental accounting literature.

\footnotetext{
${ }^{8}$ For the methodology implemented in this ranking system, see http://www.usnews.com/education/bestcolleges/articles/2012/09/11/methodology-undergraduate-ranking-criteria-and-weights-2.
} 
H1b. Students receiving grants may perceive them as a gift that creates the need to reciprocate, perhaps by taking their studies more seriously. A need to reciprocate may take the form of a greater likelihood of volunteering for good works on campus. This is a social or gift exchange argument.

We would not expect that students who participated in work-study or received loans would perceive that aid as a gift per se as the students are effectively paying for them. There are also competing hypotheses:

H2a. Students participating in work-study programs or receiving loans should perform better in college because they are more aware of the costs than those receiving only grants.

H2b. Student participating in work-study programs per se should perform worse academically because their jobs take time and energy away from academic effort.

Awareness of the costs of education may also affect enjoyments of the college experience:

H3. Students receiving grants should enjoy college more than those whose families are paying for it and should be more likely to report that college was "worth the cost." They may also report a greater willingness to continue on to graduate education for this reason.

H4a. Students participating in work-study programs and receiving loans should enjoy college less than those who are receiving financial aid in the form of grants alone because they are reminded of the cost. They are less likely to report that college was "worth the cost." They may be less inclined to continue on to graduate education for this reason.

H4b. Students in work-study programs and receiving loans may rationalize the fact that they are paying a larger cost for college than peers receiving only grants and may therefore report a greater sense that college was worth the costs.

Finally, the mental accounting literature suggests a hypothesis concerning willingness to attend and pay for education in the future: 
H5. Students paying for their college in part through loans will report less willingness to attend graduate school because their "mental account" of spending for college is lower, controlling for actual resources.

\section{Descriptive Statistics:}

Table 1a and Table 1b present means, standard deviations, and a correlation matrix for the variables used in the analysis. The sample is 57\% female and $17 \%$ non-white. Eighteen percent of the respondents were married at the time of graduation, and two-thirds attended state institutions. Table 2 shows additional descriptive statistics for the financial aid variables. Roughly half of the sample received any kind of financial aid, and grants alone on average covered about one quarter of the total cost of education.

TABLES 1a, 1b \& 2 HERE

Table 3 presents simple difference of means tests associated with the above hypotheses. Student academic performance as measured by GPA is actually higher for students who received grants and lower for those who received loans and work-study aid, the opposite of what mental accounting models might suggest but consistent with gift-exchange relationships. (Overall GPA was reported using a maximum value of 400.) Note that we expect omitted variables here to produce the opposite effect, that receiving aid is associated with attributes that lead to worse student performance.

\section{TABLE 3 HERE}

The difference of means tests for attitudes toward one's college experience are less clear, given the lack of significant relationships. Among the interesting relationships is evidence that students receiving grants are less willing to continue their education, which suggests negative 
feelings about their undergraduate experience. They are also more likely to volunteer than others, a relationship consistent with social or gift exchange. Respondents who are paying off their education through loans report less satisfaction with education, which is consistent with the mental accounting model, i.e., being reminded of the costs. We examine below whether these relationships hold up with more thorough analyses.

\section{Results:}

The results of OLS analyses in Table 4 find that students receiving financial aid have higher GPA's than those who do not, other things equal, and are more likely to participate in voluntary work, lending support to the gift exchange notion in H1b (Table 4, Models 1 and 4). The signs on willingness to enroll and on satisfaction with their experience at college are positive and the coefficient on the latter is close to traditional measures of significance.

\section{TABLE 4 HERE}

The results using institution fixed-effects for the within-college models (Models 5-8) suggest similar relationships. Students who receive grants are more likely to receive higher grades, and students who take out loans show worse performance in terms of overall GPA. We find no effect of participating in work-study.

The within-college models cannot address whether students might be sorting themselves across colleges in ways that made it easier for financial aid recipients to have better outcomes, counter to the usual assumption that financial aid recipients should do worse because of unobserved attributes associated with lower socio-economic status. The most obvious way to address the sorting of more able students is to control for measured ability, which we do. The remaining issue therefore concerns unobservable ability. We examine the possible sorting of those with the choice to attend private or public colleges among financial aid recipients and who may be more able into lower-cost public colleges. While public colleges per se are not less selective than private colleges, it is possible that some crowding out of admissions at the more selective public 
colleges might mean that better students among those who are cost-sensitive might end up at less selective public colleges.

Examining such sorting might suggest the use of a Roy selection model of the kind that Bojas (1987) used to examine whether more able individuals were more likely to immigrate to countries where they could earn more. The question we ultimately want to address, though, is whether any such self-selection influences the overall relationship between financial aid and student performance, which is a different issue.

The data show that while students in private colleges on average have higher ability compared to students in public colleges (difference $=71.45, \mathrm{p}<0.000$ ), students on financial aid in public colleges have marginally lower ability (SAT and ACT scores) compared to the students who do not receive financial aid in those college (difference $=0.06, p=0.99$ ). That would be incompatible with the sorting view, but the difference is not significant. Aid recipients in private colleges have significantly lower SAT and ACT scores compared to non-recipients (difference $=$ 34.01, $\mathrm{p}=0.0012$ ), which is consistent with the notion that there is sorting of more able students receiving aid away from private institutions.

Because we control for measured academic ability, the issue is with unmeasured aspects of ability. The test of whether sorting on unmeasured ability occurs will turn on the results for private colleges, where the expected outcome would be different than the one we are testing: if more able (unobserved ability) students receiving financial aid sorted from private to cheaper public institutions, we would expect to see better outcomes among aid recipients in public colleges, which we already find, but we would expect worse outcomes for them among the private colleges. We report OLS results separately for private and for public schools in Table 5. Students receiving financial aid in the form of grants have higher grade point averages in private colleges, which is inconsistent with a sorting story. The difficulty in finding relationships with other variables for private colleges alone may have to do with the smaller sample size there.

TABLE 5 HERE 
The nature of financial aid eligibility suggests an additional empirical test of the relationship with student outcomes. Specifically, eligibility is based on objective criteria such that applications below a cut-off score were eligible for aid while those above were not. Regression discontinuity design (RDD) was first used to examine a very similar situation, the effects of receiving scholarships on subsequent academic rewards (Thistlewaite and Campbell 1960). Among the many RDD studies that have been used in related contexts are Van der Klauuw (2002) examining financial aid and enrollment decisions within one college, Cohodes and Goodman (2014) examine new state-level merit aid programs in Massachusetts, and Castleman and Long (2013) looking at need-based aid in Florida. Nielsen, Sørensen, and Taber (2010) do something similar in exploiting a kinked aid formula in Denmark to look at enrollment decisions.

Lee and Lemieux' (2010) review notes the important constraints in using RDD analyses, including whether the subjects of the treatment can manipulate their score on the running variable that defines the treatment. If they cannot precisely shape their scores, then the variation in treatment outcomes near the cut-off for treatment can be considered randomized. A variety of new approaches now allow RDD estimates to be expanded to situations where cutoff is fuzzy, where other factors play a role, and where it is not directly observable to participants and observers (see Porter and Yi 2015).

In this case, the financial aid criterion that creates the running variable is a formula, now known as the Pell Grant Index (PGI), based on attributes of the financial situation of one's family or of the individual student for those financially independent. Calculators are available now to help predict one's eligibility for financial aid, but in the period we examine, no such tools were available. Applicants had to submit their forms based on their finances and then hear back as to their eligibility. Neither the formula nor the cutoff score for eligibility were available in advance to applicants. While it is true that one could always increase the odds of being eligible by earning or holding less money, doing so was costly. Lying about one's finances was a crime, and the Government verified applicants with audits in 32 percent of the cases for the period we 
examine. Twenty-six percent of those who applied did not meet the eligibility criteria. ${ }^{9}$ As a result, it is difficult to argue that applicants could easily adjust their scores and influence their treatment. The cutoff for eligibility, in turn for treatment, is of the sharp variety.

The dataset provides the PGI score for each individual from administrative records, and the cutoff for eligibility in this period was a score below 2200.

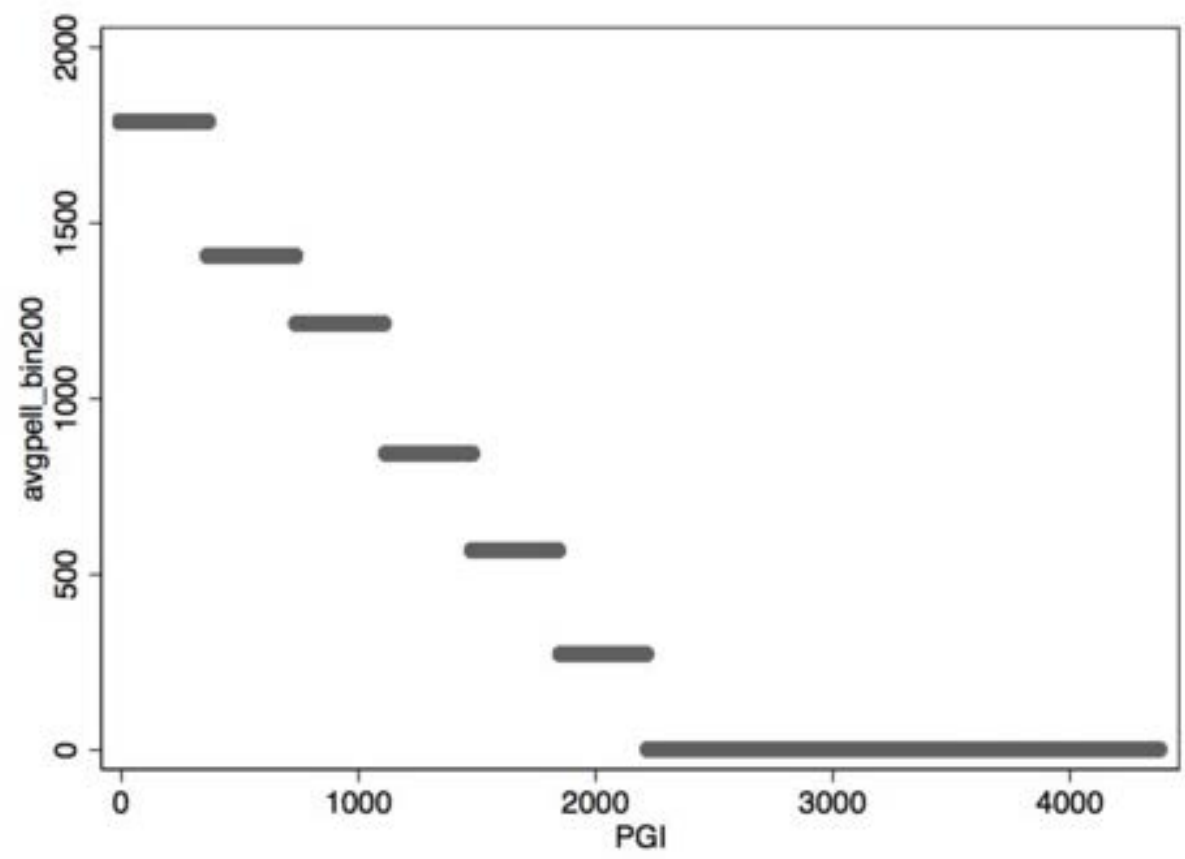

${ }^{9}$ See Pell Grant Program End-of-Year Report, 1988-1989. US Department of Education - Office of Postsecondary Improvement. Washington, D.C. https://www2.ed.gov/finaid/prof/resources/data/pell-historical/pell-eoy-198889.pdfFederal 


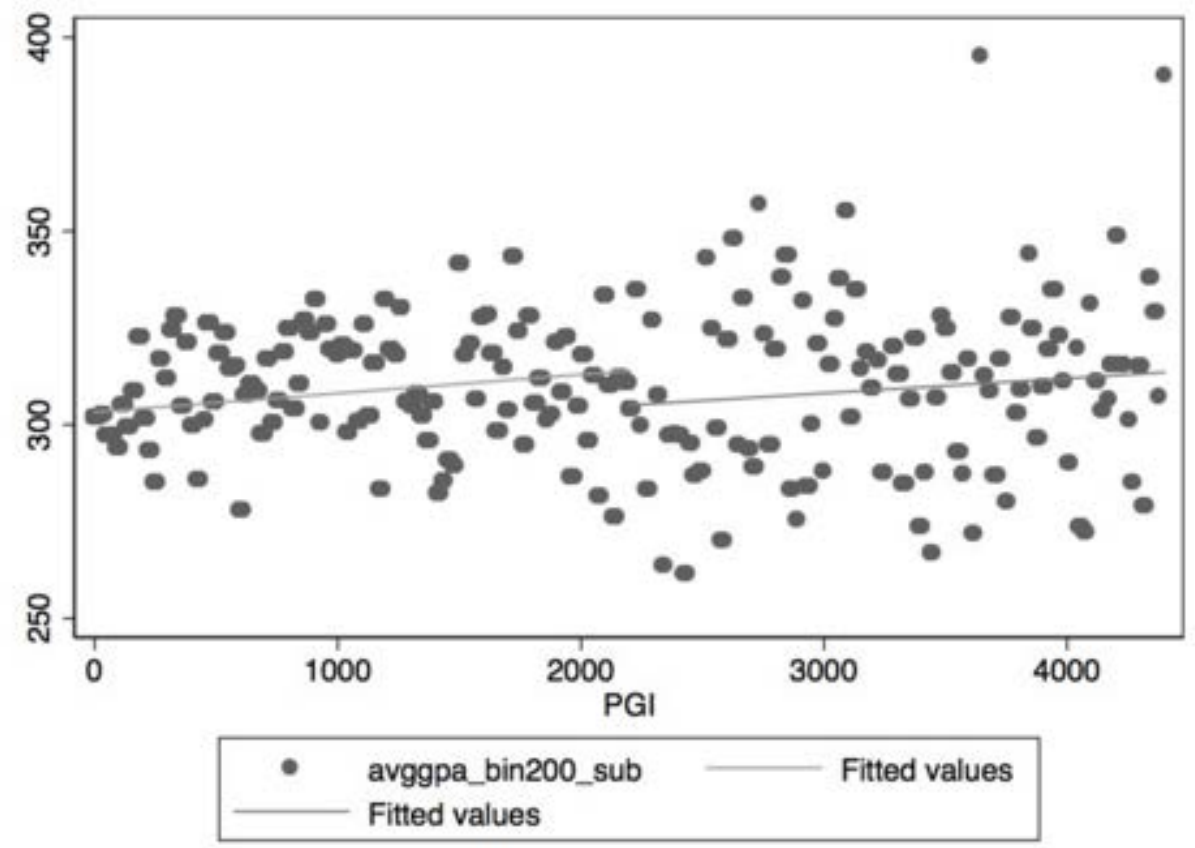

TABLE 6 HERE

The above discussion raises an issue as to whether our results might be sensitive to variations within the income levels of the comparison group. Specifically, many students who are not receiving grants/any financial aid may come from families that are very wealthy, such that the cost of college is not a serious consideration for them and the experience is essentially seen as free. Or they may come from families just above eligibility for financial aid, such that the cost of college is a serious financial burden for their families and something that might well affect the motivation of the student. In other words, assuming that all students who receive no financial aid respond equally to that situation may not be appropriate.

We examined this possibility further in analyses, available on request, where we compare the effect of grants first using as the comparison group students not receiving financial aid whose parents earned less than the median income and second a comparison group of students not receiving financial aid whose parents earned more than the median income. Those receiving 
grants perform significantly better in both cases, but the size of the coefficients was smaller where the comparison was with students from poorer families. This might suggest that students work harder when college costs are more of a burden to their families than when they are not, an issue that perhaps further analyses could explore.

Finally, we use instrumental variable analysis to address further whether unobserved initial differences between students receiving financial aid and those not receiving aid might explain the positive effect we see. We instrument the "received any grant" variable with the dummy variable that indicates whether the student applied for financial aid or not. This choice has a strong analogy to Angrist's (1990) classic use of the military draft lottery as an instrument for military service during the period of selective service via the draft: Although applying for financial aid is a necessary condition for receiving aid, as was one's lottery number a necessary condition for being drafted, it is far from a sufficient condition.

In the period we examine, 26 percent of applicants did not qualify for a grant, and 24 percent of those who were eligible did not receive one (see footnote 9). More recently, $15.47 \%$ of the students who applied for financial aid did not receive any, and 2.3 million who were eligible for aid did not apply, the equivalent of $20 \%$ of those who did apply (Kantrowitz 2009). The instrument is correlated with the probability of receiving financial aid (correlation $=0.8496$ ). There is not a strong case for thinking that applying for aid per se has any effect on student performance other than through its effect on receiving financial aid, the exclusion restriction: The practice in college applications was to include material about financial aid along with admissions material, so there was no need to seek out information about applying for aid. The burden of applying for aid might be different from that in applying for admission, of course. Wealthier families whose finances are likely to be more complicated would find it more difficult to do, but they also have greater resources for compiling the material; poor families are likely to have simple finances, but they may have less ability to gather and report the information. Fiftynine percent of those in our sample applied for aid for aid. The results, presented in Table 7, are consistent with other specifications. 


\section{TABLE 7 HERE}

\section{Conclusions:}

There is considerable evidence for the idea that how one pays for something might affect how one experiences it. That notion is especially relevant in the context of higher education, where huge sums of taxpayer money shape how millions of students pay for college. There has been surprisingly little research to examine the effects of the different forms of financial aid. One outcome, academic performance, has life-long implications for the participants as it affects how much they learn, access to further education and, to some extent, to jobs.

Results suggest that how one pays for college does affect performance in college as measured by grades. We find that students receiving financial aid grants perform significantly better than those who are not receiving financial aid, consistent with a social or gift exchange notion that the grants create pressure to reciprocate by taking academic performance more seriously. There is considerable consistency across specifications as to the size of the effect, grades about 0.08 to 0.15 points higher on a 4.00 scale, about one quarter of a standard deviation. Students who receive student loans receive grades roughly 0.6 to 0.12 points lower than those receiving financial aid not in the form of loans, again other things equal and across different specifications.

The fact that students with loans viewed their education as less worthwhile than those who only received grants is consistent with the notion of mental accounting, where the reminder of the payment makes them more critical of what they paid for. Students receiving grants only were somewhat more likely to do volunteer work, consistent with the notion that the latter experienced less of a social or gift exchange because they were paying for part of their education. The addition of loans may cause students to ignore the "gift" they also received in the form of grants, at least in comparison to those who only had grants.

Overall, though, the notion that making students more responsible for the costs of their education will make them take it more seriously is not supported by these results. Indeed, adding loans to a student's financial aid package is associated with worse performance. 
The general view has been that students who receive financial aid have unobserved attributes that cause them to perform worse in college. No doubt some of those attributes are unobserved here as well. Controlling for them should increase the estimates. The possibility remains that some unobserved attributes associated with financial aid may actually increase student achievement and continues to be worth considering.

The Hamilton (2013) study noted above also uses the B\&B data and finds that the greater the contribution that parents make to a student's college-related expenses, the worse the student performs in terms of GPA. The implication is that if education is free to the student, they will not take it as seriously nor perform as well, a conclusion at odds with our results here that students who receive grants only, essentially free money, perform better while students who are paying for their education through loans that must be paid back perform worse.

The implicit assumption in Hamilton study is that if parents supply less financial support, then the students have to pay more themselves. That assumption is not true, however, with the exception of mature students who are financially independent of their parents. Those students are truly responsible for the costs of their own education. (Using our estimation models, available on request, such students perform significantly worse in terms of GPA, other things equal.) The actual trade-off is between parental support and financial aid, and that is not a choice within the control of parents or students. Students whose parents could afford to pay for their children's college education cannot receive financial aid in this period, and that includes getting access to loans. What parents can control is pocket money, the amount over and above the tuition and fee requirements that are covered by financial aid. Hamilton's analyses controls for financial aid, so for students receiving substantial amounts of aid, parent contributes by definition are limited to pocket money, which has quite different implications. ${ }^{10}$

\footnotetext{
${ }^{10}$ It is possible that parents can require that their children pay back the parent's contribution or contribute money they earned in high school, but such arrangements are not observable in these data. One puzzling aspect of Hamilton's (2013) findings is that the students who perform best are those whose families are providing no financial support at all. Even a small payment by parents at any income level is associated with a sharp decline in GPA. A possible explanation for this result has to do with scholarships that are not need-based, merit-based scholarships, which are not controlled for in Hamilton's analysis. Even though they were quite rare in this period, such meritbased scholarships would be about the only way that a wealthy child could go through college without support from their families. A "full-ride," complete athletic scholarship or possibly one of the few merit scholarships like the National Merit Scholarship program would create the kind of omitted variable bias that could explain the finding
} 
The implications for policy here are straight-forward. The tendency in recent years to shift financial aid to loans may well come with a cost in terms of student achievement. The general notion that making students pay for their education will also make them take it more seriously and that this, in turn, will make them perform better should be questioned.

here: Highly able students who then perform very well require no financial support from even wealthy parents. The merit-based scholarship control variable in our analyses is strongly correlated with all measures of academic performance. Perhaps because we include merit aid in our analyses, we do not replicate Hamilton's findings concerning parental support. The relationships are insignificant except for Math GPA where greater support is associated with higher GPA. We also do not impute estimates to fill in missing data. 


\section{BIBLIOGRAPHY}

Alon, Sigal and Marta Tienda. 2007. Diversity, Opportunity, and the Shifting Meritocracy in Higher Education. American Sociological Review. 72(4): 487-511.

Alon, Sigal. 2005. Model Mis-Specification In Assessing The Impact of Financial Aid on Academic Outcomes. Research in Higher Education. 46(1):109-125.

Alwin, Duane F. 1974. College Effects on Educational and Occupational Attainments. American Sociological Review, 39(2): 213-223.

Arkes, Hal. R. and Catherine Blumer. 1985. The Psychology of Sunk Cost. Organizational Behavior and Human Decision Processes. 35: 124-140.

Bagozzi, R.P. 1974. “Marketing as an Organized Behavioural System of Exchange.” Journal of Marketing, 38: 77-82.

Baker, Therese L. and William Vélez. 1996. Access to and Opportunity in Postsecondary Education in the United States: A Review. Sociology of Education. 69(2): 82-101.

Banerjee, Smita C., Jennifer L. Hay, and Kathryn Greene. 2013. Cognitive Rationalizations for Tanning-Bed Use: A Preliminary Exploration. American Journal of Health Behavior. 37(5): 577-586.

Bellemare, C., \& Shearer, B. 2009. Gift giving and worker productivity: Evidence from a firmlevel experiment. Games and Economic Behavior, 67(1), 233-244.

Brown, Meta; Karl Scholz, John; Seshadri, Ananth. 2012. A New Test of Borrowing Constraints for Education. Review of Economic Studies. 79(2): 511-538.

Buchmann, Claudia and Thomas A. DiPrete. 2006. “The Growing Female Advantage in College Completion: The Role of Family Background and Academic Achievement.” American Sociological Review 71:515-41.

Cage, Mary Crystal. 1993. The "Need Blind" Admission Dilemma. The Chronicle of Higher Education, 10/27/1993. Accessed as http://proxy.library.upenn.edu:2092/article/The-NeedBlind-Admission/90579/

Cadr, David, Alexandre Mas, and Jesse Rothstein. 2008. Tipping and the Dynamics of Segregation. Quarterly Journal of Economics 177-218.

Castleman, Benjamin L. and Bridget Terry Long. 2013. Looking Beyond Enrollment: The Causal Effect of Need-Based Grants on College Access, Persistence, and Graduation. NBER Working Paper 19306.

Charness, G., Frechette, G. R., \& Kagel, J. H. 2004. How robust is laboratory gift exchange? Experimental Economics, 7(2), 189-205. 
Chen, Rong and Edward P. St. John. 2011. State Financial Policies and College Student Persistence: A National Study. Journal of Higher Education. 82(5): 5, 629-660.

Clotfelter, Charles T. 1991. Financial Aid and Public Policy in Charles T. Clotfelter, Ronald G. Ehrenberg, Malcolm Getz, and John J. Siegfried (eds). Economic Challenges in Higher Education. Chicago: University of Chicago Press, pp.89-123.

Cohodes, Sarah, and Joshua Goodman. 2014. Merit Aid, College Quality and College Completion: Massachusetts’ Adams Scholarship as an In-Kind Subsidy, American Economic Journal: Applied Economics 6, no. 4: 251-285.

Darolia, R. (2014). Working (and studying) day and night: Heterogeneous effects of working on the academic performance of full- time and part- time students. Economics of Education Review, 38, 38- 50.

Delaney, Liam, Colm Harmon, Martin Ryan. 2013. The role of noncognitive traits in undergraduate study behaviours. Economics of Education Review, 32(1): 181-195

Deming, David and Susan Dynarski. 2009. Into College, Out of Poverty? Policies to Increase the Postsecondary Attainment of the Poor. NBER Working Paper No. 15387

DesJardins, Stephen L., Dennis A. Ahlburg, and Brian P. McCall. 2002. Simulating the Longitudinal Effects of Changes in Financial Aid on Student Departure from College. Journal of Human Resources. 37(3): 653-679.

Downey, Douglas B. 1995. "When Bigger Is Not Better: Family Size, Parental Resources, and Children’s Educational Performance.” American Sociological Review 60:746-61.

Dresch, Stephen P. 1975. A Critique of Planning Models for Postsecondary Education: Current Feasibility, Political Relevance, and a Prospectus for Future Research. Journal of Higher Education 46: 246-286.

Dynarski, S. 2002. . Does aid matter? Measuring the effect of student aid on college attendance and completion. American Economic Review. 93(1):279-88

Falk, A. 2007. Gift exchange in the field. Econometrica. 75(5), 1501-1511.

Fehr, E., Goette, L., \& Zehnder, C. 2009. A behavioral account of the labor market: The role of fairness concerns. Annu. Rev. Econ. 1(1), 355-384.

Fehr, E., Kirchler, E., Weichbold, A., \& Gächter, S. 1998. When social norms overpower competition: Gift exchange in experimental labor markets. Journal of Labor economics, 16(2), 324-351.

Fehr, E., Kirchsteiger, G., \& Riedl, A. 1993. Does fairness prevent market clearing? An experimental investigation. The Quarterly Journal of Economics,108(2), 437-459.

Festinger, Leon. 1957. A Theory of Cognitive Dissonance. Palo Alto, CA: Stanford University Press. 
Fuchs, Galia, Natan Uriely, Arie Reichel, and Darya Maoz. 2013. Vacationing in a TerrorStricken Destination: Tourists’ Risk Perceptions and Rationalizations. Journal of Travel Research. 52(2): 182-191.

Gneezy, U., \& List, J. A. 2006. Putting behavioral economics to work: Testing for gift exchange in labor markets using field experiments. Econometrica, 74(5), 1365-1384.

Gourville, John T. and Dilip Soman. 1998. Payment Depreciation: The Behavioral Effects of Temporarally Separating Payments from Consumption. Journal of Consumer Research 25:160-

Greene, William. 2006. A General Approach to Incorporating Selectivity in a Model. Stern School of Business, New York University working paper.

Hamilton, L. T. 2013. More is more or more is less? Parental financial investments during college. American Sociological Review, 78(1), 70-95.

Hannan, R. L., Kagel, J. H., \& Moser, D. V. 2002. Partial Gift Exchange in an Experimental Labor Market: Impact of Subject Population Differences, Productivity Differences, and Effort Requests on Behavior. Journal of Labor Economics, 20(4), 923-951.

Hastings, Justine and Jesse M. Shapiro. 2012. Mental Accounting and Consumer Choice: Evidence from Commodity Price Shocks. Boston: NBER Working Paper 18248.

Hauptman, Arthur M. 1990. Navigating the maze of new college financing options. Brookings Review. 8(2): 32-39.

Hirschman, Elizabeth. 1979. Differences in consumer purchase behavior by credit card payment system. Journal of Consumer Research (6):58-66.

Hoxby, Caroline M. (ed) 2004. In College choices: The economics of where to go, when to go and how to pay for it, ed. Chicago: University of Chicago Press.

Jackson, Toby. 2010. How Scholarships Morphed into Financial Aid. Academic Questions. 23(3): 298-310.

Kantrowitz, Mark. 2009. Analysis of Why Some Students Do Not Apply for Financial Aid. FinAid.Org. http://www.finaid.org/educators/20090427CharacteristicsOfNonApplicants.pdf

Kay, Aaron C. Maria C. Jimenez, and John T. Jost. 2002. Sour grapes, sweet lemons, and the anticipatory rationalization of the status quo. Personality and Social Psychology Bulletin: 1300-1312.

Lee, David S. and Thomas Lemieux. 2010. Regression Discontinuity Designs in Economics: A Review. Journal of Economic Literature. 48: 281-355. 
Lee, D., \& Rupp, N. G. 2007. Retracting a gift: How does employee effort respond to wage reductions? Journal of Labor Economics, 25(4), 725-761.

Masten, Scott E. 1995. Old school ties: Financial aid coordination and the governance of higher education. Journal of Economic Behavior \& Organization. 28(1): 23-48.

Matlock, Thao P. 1994. The Overlap Group: A Study of Nonprofit Competition. Journal of Law and Education 23: 523.

Maximiano, S., Sloof, R., \& Sonnemans, J. 2007. Gift Exchange in a Multi- Worker Firm*. The Economic Journal, 117(522), 1025-1050.

McCall, Leslie. 2000. Gender and the New inequality: Explaining the College/Non-College Wage Gap. American Sociological Review, 65(2): 234-255.

Meer, Jonathan and Harvey S. Rosen. 2012. Does Generosity Beget Generosity? Alumni Giving and Undergraduate Financial Aid. Economics of Education Review. 31(6): 890-907.

NCES. 2005. 1993/03 Baccalaureate and Beyond Longitudinal Study: Methodology Report. Washington, DC: US Department of Education, Institute of Educational Sciences.

NCES. 2008. Ten Years After College: Comparing the Employment Experiences of 1992-93 Bachelor's Degree Recipients With Academic and Career-Oriented Majors. Washington: National Center for Educational Statistics, Institute of Educational Sciences. 2008. Descriptive data.

Nielsen, H. S.; Sørensen, T.; Taber, C. R. (2010). "Estimating the Effect of Student Aid on College Enrollment: Evidence from a Government Grant Policy Reform". American Economic Journal: Economic Policy 2 (2): 185-215.

Nurnberg , Peter, Morton Schapiro, David Zimmerman. 2012. Students choosing colleges: Understanding the matriculation decision at a highly selective private institution. Economics of Education Review, 31(1): 1-8.

Parscarella, Ernest T. and Patrick T. Terenzini. 2005. How College Affects Students. San Francisco: Jossey-Bass, Volume 2.

Porter, Jack and Ping Yu. 2015. Regression Discontinuity Designs with Unknown Discontinuity Points: Testing and Estimation. Journal of Econometrics. 189: 132-147.

Prelec, Drazen and George Loewenstein. 1998. The Red and the Black: Mental Accounting of Savings and Debt. Marketing Science 17(1):4-28.

Schmitt, Neil, Frederick L. Oswald, Brian H. Kim, Anna Imus, Stephanie Merritt, Alyssa Friede, and Smriti Shivpuri. 2007. The Use of Background and Ability Profiles to Predict College Student Outcomes. Journal of Applied Psychology. 92(1): 165-179.

J. Scott-Clayton 2011. The causal effect of federal work-study participation: Quasi-experimental evidence from West Virginia. Educational Evaluation and Policy Analysis, 33 (4): 506-527 
Scott-Clayton, Judith 2011. On Money and Motivation.Journal of Human Resources. 46(3): 614646.

Judith Scott-Clayton and Veronica Minaya. 2014. Should Student Employment be Subsidized? Conditional Counterfactuals and the Outcomes of Work-Study Participation. NBER working paper 20329.

Soman, Dilip and Lam, Vivian M. W. 2002. The Effects of Prior Spending on Future Spending Decisions: The Role of Acquisition Liabilities and Payments. Marketing Letters. Nov2002, Vol. 13 Issue 4, p359-372.

Soman, Dilip. 2001. "Effects of Payment Mechanism on Spending Behavior: The Role of Rehearsal and Immediacy of Payments," Journal of Consumer Research, 27(4), 460-474.

Sque, M., and S. A. Payne. 1994. "Gift Exchange Theory: a critique in relation to organ transplantation,” Journal of Advanced Nursing, 19(1), 45-51.

Steelman, Lala Carr and Brian Powell. 1989. Acquiring Capital for College: The Constraints of Family Configuration. American Sociological Review 54:844-55.

Stinebrickner, R., and T. R. Stinebrickner. 2003. Working during school and academic performance. Journal of Labor Economics 21(2):473-91.

Thaler, Richard H. 1980. Toward a Positive Theory of Consumer Choice. Journal of Economic Behavior and Organization 1:39-60.

Thaler, Richard. 1985. "Mental accounting and consumer choice." Marketing science 4: 199-214.

Thistlethwaite, Donald L., and Donald T. Campbell. 1960. "Regression-Discontinuity Analysis: An Alternative to the Ex Post Facto Experiment.” Journal of Educational Psychology, 51(6): 309-17.

Tritch, Teresa. 1990. Borrowing to Bridge the Gap Where to turn when financial aid or savings don't cover your college costs. Money. September $10^{\text {th }} 1990$, p52.

Triventi, Moris. 2014. Does working during higher education affect students' academic progression? Economics of Education Review, 41(4): 1-13.

van der Klaauw, Wilbert. 2002. "Estimating the Effect of Financial Aid Offers on College Enrollment: A Regression-Discontinuity Approach. International Economic Review, 43(4): 1249-87. 
Table 1a. Descriptive Statistics: Correlations

\begin{tabular}{|c|c|c|c|c|c|c|c|c|c|c|c|c|c|}
\hline & & (1) & $(2)$ & (3) & (4) & (5) & (6) & (7) & (8) & (9) & $(10)$ & $(11)$ & $(12)$ \\
\hline$(1)$ & Received any grant & 1 & & & & & & & & & & & \\
\hline$(2)$ & Received any loan & 0.48 & 1 & & & & & & & & & & \\
\hline (3) & Received any workstudy & 0.29 & 0.31 & 1 & & & & & & & & & \\
\hline (4) & Grant amount & 0.61 & 0.65 & 0.46 & 1 & & & & & & & & \\
\hline (5) & Loan amount & 0.39 & 0.8 & 0.27 & 0.73 & 1 & & & & & & & \\
\hline$(6)$ & Workstudy amount & 0.23 & 0.22 & 0.77 & 0.4 & 0.2 & 1 & & & & & & \\
\hline$(7)$ & GPA & 0.14 & 0.01 & 0.04 & 0.09 & 0.02 & 0.04 & 1 & & & & & \\
\hline$(8)$ & Willingness to enroll & 0.02 & 0.02 & -0.01 & 0.01 & 0 & -0.01 & -0.02 & 1 & & & & \\
\hline (9) & Satisfaction in 2003 & -0.02 & -0.07 & -0.04 & -0.07 & -0.08 & -0.03 & 0.07 & 0 & 1 & & & \\
\hline $\begin{array}{c}(10 \\
)\end{array}$ & Voluntary work & 0.04 & 0.02 & 0.02 & 0.04 & 0.02 & 0.02 & 0.07 & 0.02 & 0.01 & 1 & & \\
\hline$\stackrel{(11}{)}$ & Female & 0.03 & 0.03 & 0.02 & -0.01 & 0 & 0.01 & 0.16 & 0.01 & 0.01 & 0.06 & 1 & \\
\hline$\stackrel{(12}{)}$ & Age & 0.04 & 0 & -0.09 & -0.04 & 0.02 & -0.06 & 0.16 & 0.03 & 0.02 & 0.11 & 0.06 & 1 \\
\hline$\stackrel{(13}{)}$ & Black & 0.08 & 0.07 & 0.05 & 0.08 & 0.06 & 0.02 & -0.15 & 0.07 & -0.01 & 0.05 & 0.05 & 0.03 \\
\hline $\begin{array}{c}(14 \\
)\end{array}$ & Hispanic & 0.05 & 0.01 & 0.02 & 0.02 & 0 & 0.01 & -0.06 & 0.05 & -0.01 & -0.02 & 0.02 & 0.02 \\
\hline$\stackrel{(15}{)}$ & Asian & -0.01 & -0.04 & 0 & 0 & -0.03 & 0.02 & -0.02 & 0.01 & -0.01 & -0.02 & -0.04 & -0.04 \\
\hline (16 & Marital status & 0.01 & -0.04 & -0.07 & -0.07 & -0.02 & -0.05 & 0.17 & -0.02 & 0.04 & 0.09 & 0.06 & 0.45 \\
\hline $\begin{array}{l}(17 \\
)\end{array}$ & SAT/ACT score & 0.01 & -0.03 & 0.07 & 0.12 & 0.01 & 0.1 & 0.29 & 0 & -0.03 & 0.06 & -0.15 & -0.1 \\
\hline $\begin{array}{c}(18 \\
)\end{array}$ & Log(Household income) & -0.3 & -0.27 & -0.09 & -0.23 & -0.23 & -0.06 & 0.08 & 0.01 & 0.04 & 0.01 & 0.03 & -0.14 \\
\hline (19 & Mother's education & -0.11 & -0.1 & 0 & -0.05 & -0.07 & 0 & 0.02 & -0.03 & 0 & 0.02 & -0.04 & -0.25 \\
\hline$\stackrel{(20}{)}$ & Father's education & -0.13 & -0.12 & -0.01 & -0.06 & -0.08 & 0 & 0.01 & -0.03 & 0.01 & 0 & -0.06 & -0.27 \\
\hline $\begin{array}{c}(21 \\
)\end{array}$ & Private institution & 0.2 & 0.17 & 0.2 & 0.35 & 0.21 & 0.15 & 0.13 & 0.03 & -0.11 & 0.05 & 0.01 & 0 \\
\hline $\begin{array}{c}(22 \\
)\end{array}$ & Selectivity & 0.07 & 0.03 & -0.03 & -0.06 & 0 & -0.05 & -0.01 & 0 & 0 & -0.01 & 0.08 & 0.2 \\
\hline$\stackrel{(23}{)}$ & Institution cost & 0.19 & 0.23 & 0.19 & 0.43 & 0.31 & 0.16 & 0.13 & 0.03 & -0.08 & 0.05 & 0.01 & -0.11 \\
\hline$(24$ & $\begin{array}{l}\text { Number of family } \\
\text { members }\end{array}$ & -0.01 & 0 & 0.05 & 0.02 & -0.01 & 0.03 & -0.05 & 0 & -0.01 & -0.01 & -0.02 & -0.36 \\
\hline $\begin{array}{c}(25 \\
)\end{array}$ & Applied for aid & 0.31 & 0.31 & 0.17 & 0.33 & 0.28 & 0.12 & 0.11 & -0.05 & -0.04 & 0.01 & -0.01 & -0.06 \\
\hline & & (13) & $(14)$ & (15) & $(16)$ & $(17)$ & (18) & $(19)$ & $(20)$ & $(21)$ & $(22)$ & $(23)$ & (24) \\
\hline (14 & Hispanic & -0.06 & 1 & & & & & & & & & & \\
\hline$\stackrel{(15}{)}$ & Asian & -0.05 & -0.05 & 1 & & & & & & & & & \\
\hline$\stackrel{(16}{)}$ & Marital status & -0.05 & 0.01 & -0.05 & 1 & & & & & & & & \\
\hline$\stackrel{(17}{)}$ & SAT/ACT score & -0.18 & -0.07 & 0.08 & -0.07 & 1 & & & & & & & \\
\hline$\stackrel{(18}{)}$ & Log(Household income) & -0.09 & -0.1 & -0.03 & -0.01 & 0.18 & 1 & & & & & & \\
\hline (19 & Mother's education & -0.04 & -0.11 & 0.01 & -0.17 & 0.27 & 0.19 & 1 & & & & & \\
\hline$\stackrel{(20}{)}$ & Father's education & -0.09 & -0.09 & 0.04 & -0.17 & 0.29 & 0.22 & 0.57 & 1 & & & & \\
\hline
\end{tabular}




\begin{tabular}{|c|c|c|c|c|c|c|c|c|c|c|c|c|c|}
\hline$\stackrel{(21}{)}$ & Private institution & 0.03 & 0.01 & -0.01 & -0.02 & 0.19 & 0.08 & 0.06 & 0.06 & 1 & & & \\
\hline $\begin{array}{c}(22 \\
)\end{array}$ & Selectivity & 0.06 & 0.01 & -0.12 & 0.15 & -0.45 & -0.16 & -0.22 & -0.22 & 0 & 1 & & \\
\hline $\begin{array}{c}(23 \\
)\end{array}$ & Institution cost & -0.01 & -0.04 & 0.03 & -0.05 & 0.28 & 0.14 & 0.15 & 0.14 & 0.5 & -0.23 & 1 & \\
\hline $\begin{array}{c}(24 \\
)\end{array}$ & $\begin{array}{l}\text { Number of family } \\
\text { members }\end{array}$ & -0.03 & 0.04 & 0.08 & -0.2 & 0.04 & 0.11 & 0.12 & 0.17 & 0.03 & -0.09 & 0.04 & 1 \\
\hline $\begin{array}{c}(25 \\
)\end{array}$ & Applied for aid & 0.02 & 0.01 & 0 & -0.07 & 0.14 & -0.13 & 0 & 0 & 0.08 & -0.07 & 0.12 & 0.01 \\
\hline
\end{tabular}

Table 1b. Descriptive Statistics: Means and Standard Deviations

\begin{tabular}{|c|c|c|}
\hline Variable & Mean & Std. Dev. \\
\hline \multicolumn{3}{|l|}{ Key independent variables } \\
\hline Received any grant & 0.539 & 0.498 \\
\hline Received any loan & 0.323 & 0.468 \\
\hline Received any work-study & 0.102 & 0.303 \\
\hline Amount of grant (per year) & $\$ 3082.195$ & 4414.274 \\
\hline Amount of loan & $\$ 1211.311$ & 2136.443 \\
\hline Amount of work-study & $\$ 140.437$ & 537.225 \\
\hline \multicolumn{3}{|l|}{ Dependent variables } \\
\hline GPA (on a 400 point scale) & 306.440 & 50.147 \\
\hline GPA in math (on a 4 point scale) & 2.600 & 0.990 \\
\hline GPA in humanities & 3.049 & 0.619 \\
\hline Willingness to enroll in graduate studies (0/1) & 0.701 & 0.458 \\
\hline Satisfaction in college education $(0 / 1)$ & 0.897 & 0.304 \\
\hline Participated in voluntary work (0/1) & 0.354 & 0.478 \\
\hline \multicolumn{3}{|l|}{ Control variables } \\
\hline \multicolumn{3}{|l|}{ Sociodemographics } \\
\hline Female & 0.566 & 0.496 \\
\hline Age & 25.017 & 6.621 \\
\hline Black & 0.061 & 0.239 \\
\hline Hispanic & 0.052 & 0.223 \\
\hline Asian & 0.043 & 0.203 \\
\hline Marital status in 1993 & 0.191 & 0.393 \\
\hline Financially independent & 0.387 & 0.487 \\
\hline \multicolumn{3}{|l|}{ Academic ability } \\
\hline SAT/ACT score & 1056.441 & 118.0621 \\
\hline \multicolumn{3}{|l|}{ Parental SES and family structure } \\
\hline \multicolumn{3}{|l|}{$\begin{array}{l}\text { Mother's education (base: Less than high } \\
\text { school) }\end{array}$} \\
\hline High school graduate & 0.385 & 0.487 \\
\hline Some PSE & 0.107 & 0.309 \\
\hline 2 years or more of PSE & 0.097 & 0.295 \\
\hline Bachelor's degree & 0.214 & 0.410 \\
\hline
\end{tabular}


Advanced degree

Father's education (base: Less than high school)

High school graduate

0.310

0.463

Some PSE

0.089

0.285

2 years or more of PSE

0.069

0.253

Bachelor's degree

0.227

0.419

Advanced degree

0.218

0.413

Number of members in college

3.620

1.387

Institution Characteristics

Private institution

0.350

0.477

Institution selectivity

Institution cost (per year)

Instrumental variable

Applied for financial aid

0.534

0.499

Table 2. Descriptive statistics for the financial aid variables

\begin{tabular}{lcccrc||ccc}
\hline & $\begin{array}{c}\text { \% of } \\
\text { students }\end{array}$ & \multicolumn{3}{c||}{ Dollar amount } & \multicolumn{2}{c}{ \% of total education } \\
& Receiving & Mean & Std & Min & Max & Mean & Std \\
\hline Grant & 0.5435132 & 3082.195 & 4414.274 & 70 & 37793 & $25.87 \%$ & $31.77 \%$ \\
Workstudy & 0.1063259 & 140.4369 & 537.2247 & 100 & 10000 & $13.10 \%$ & $24.05 \%$ \\
Loan & 0.3482845 & 1211.311 & 2136.443 & 100 & 23500 & $2.51 \%$ & $12.63 \%$ \\
\hline
\end{tabular}

Table 3. Difference in Means between grantees and non-grantees

\begin{tabular}{lcccc}
\hline $\begin{array}{l}\text { Difference in } \\
\text { means }\end{array}$ & GPA & $\begin{array}{c}\text { Willingness } \\
\text { to enroll }\end{array}$ & $\begin{array}{c}\text { Satisfaction } \\
\text { in } 2003\end{array}$ & $\begin{array}{c}\text { Voluntary } \\
\text { work }\end{array}$ \\
\hline Grant & $20.300^{* *}$ & 0.015 & $0.028^{* *}$ & $0.061^{* *}$ \\
Work study & $-5.451+$ & -0.018 & 0.013 & 0.002 \\
Loan & $-14.903^{* *}$ & 0.010 & $-0.057^{* *}$ & $-0.029+$ \\
\hline \multicolumn{4}{c}{${ }^{* *} \mathrm{p}<0.01,{ }^{*} \mathrm{p}<0.05,+\mathrm{p}<0.1$}
\end{tabular}


Table 4. Effect of financial aid on academic and non-academic outcomes

\begin{tabular}{|c|c|c|c|c|c|c|c|c|}
\hline & \multicolumn{4}{|c|}{ OLS } & \multicolumn{4}{|c|}{ Institution fixed effect } \\
\hline & (1) & (2) & (3) & (4) & (5) & (6) & (7) & (8) \\
\hline & GPA & $\begin{array}{l}\text { Willingness } \\
\text { to enroll }\end{array}$ & $\begin{array}{l}\text { Satisfaction } \\
\text { in } 2003\end{array}$ & $\begin{array}{l}\text { Voluntary } \\
\text { work }\end{array}$ & GPA & $\begin{array}{l}\text { Willingness } \\
\text { to enroll }\end{array}$ & $\begin{array}{l}\text { Satisfaction } \\
\text { in } 2003\end{array}$ & $\begin{array}{l}\text { Voluntary } \\
\text { work }\end{array}$ \\
\hline \multirow[t]{2}{*}{ Received any grant } & $12.09 * * *$ & 0.0051 & 0.0235 & $0.0512^{*}$ & $12.19 * * *$ & 0.0051 & 0.024 & $0.0512 *$ \\
\hline & {$[2.851]$} & {$[0.0327]$} & {$[0.0213]$} & {$[0.0296]$} & [2.817] & {$[0.0327]$} & {$[0.0213]$} & {$[0.0296]$} \\
\hline \multirow[t]{2}{*}{ Received any loan } & $-6.892 * *$ & 0.018 & -0.0195 & $-0.0747 * *$ & $-6.616 * *$ & 0.018 & -0.0206 & $-0.0747 * *$ \\
\hline & [3.060] & {$[0.0347]$} & {$[0.0231]$} & [0.0319] & [3.024] & {$[0.0347]$} & {$[0.0231]$} & [0.0319] \\
\hline \multirow{2}{*}{$\begin{array}{l}\text { Received any work- } \\
\text { study }\end{array}$} & 0.402 & 0.0351 & -0.0264 & 0.0526 & -0.898 & 0.0351 & -0.0194 & 0.0526 \\
\hline & [3.483] & {$[0.0379]$} & {$[0.0259]$} & {$[0.0361]$} & {$[3.481]$} & {$[0.0379]$} & {$[0.0261]$} & {$[0.0361]$} \\
\hline \multirow[t]{2}{*}{ SAT/ACT score } & $0.0761 * * *$ & 8.43E-05 & $1.01 \mathrm{E}-06$ & $0.000169 * * *$ & $0.0766^{* * *}$ & 8.43E-05 & $-6.54 \mathrm{E}-06$ & $0.000169 * * *$ \\
\hline & {$[0.00598]$} & [6.77e-05] & [4.46e-05] & [6.19e-05] & {$[0.00602]$} & [6.77e-05] & [4.52e-05] & [6.19e-05] \\
\hline \multirow[t]{2}{*}{ Female } & $21.31 * * *$ & 0.0117 & -0.0132 & $0.0726^{* * *}$ & $20.40 * * *$ & 0.0117 & -0.0129 & $0.0726 * * *$ \\
\hline & [1.902] & {$[0.0218]$} & [0.0142] & {$[0.0198]$} & [1.877] & [0.0218] & [0.0142] & [0.0198] \\
\hline \multirow[t]{2}{*}{ Age } & 0.421 & $-9.23 E-07$ & 0.00286 & $0.00804 * * *$ & 0.316 & $-9.23 E-07$ & 0.00273 & $0.00804 * * *$ \\
\hline & [0.299] & {$[0.00341]$} & {$[0.00217]$} & {$[0.00310]$} & [0.296] & {$[0.00341]$} & [0.00218] & [0.00310] \\
\hline \multirow[t]{2}{*}{ Black } & $-31.36^{* * *}$ & $0.121 * *$ & 0.00226 & $0.0891^{*}$ & $-32.80 * * *$ & $0.121^{* *}$ & -0.00917 & $0.0891^{*}$ \\
\hline & [4.614] & [0.0485] & {$[0.0350]$} & [0.0481] & [4.651] & [0.0485] & [0.0354] & [0.0481] \\
\hline \multirow[t]{2}{*}{ Hisp } & $-12.59 * * *$ & $0.129 * *$ & -0.00356 & -0.0727 & $-11.40 * *$ & $0.129 * *$ & -0.0055 & -0.0727 \\
\hline & {$[4.437]$} & {$[0.0500]$} & {$[0.0335]$} & {$[0.0459]$} & {$[4.488]$} & {$[0.0500]$} & {$[0.0340]$} & {$[0.0459]$} \\
\hline \multirow[t]{2}{*}{ Asian } & -6.023 & -0.00943 & -0.00988 & -0.0303 & -6.246 & -0.00943 & -0.0194 & -0.0303 \\
\hline & [3.854] & {$[0.0436]$} & [0.0303] & [0.0405] & [3.895] & [0.0436] & [0.0308] & [0.0405] \\
\hline \multirow[t]{2}{*}{ Marital status in 1993} & $18.84 * * *$ & -0.036 & 0.0211 & $0.0861^{* *}$ & $19.57 * * *$ & -0.036 & 0.0183 & $0.0861 * *$ \\
\hline & {$[3.716]$} & {$[0.0434]$} & {$[0.0275]$} & {$[0.0389]$} & {$[3.671]$} & {$[0.0434]$} & {$[0.0275]$} & {$[0.0389]$} \\
\hline \multirow{2}{*}{$\begin{array}{l}\text { Log of household } \\
\text { income }\end{array}$} & 1.232 & 0.00286 & $0.0126^{*}$ & -0.00283 & $1.568^{*}$ & 0.00286 & $0.0129 *$ & -0.00283 \\
\hline & {$[0.918]$} & [0.0104] & [0.00693] & [0.00965] & [0.906] & {$[0.0104]$} & [0.00694] & [0.00965] \\
\hline \multirow[t]{2}{*}{ Selectivity } & -0.295 & -0.0063 & -0.00222 & $-0.0119 *$ & -0.3 & -0.0063 & $-3.27 E-05$ & $-0.0119 *$ \\
\hline & [0.591] & [0.00667] & {$[0.00440]$} & [0.00615] & {$[0.758]$} & {$[0.00667]$} & [0.00513] & {$[0.00615]$} \\
\hline \multirow[t]{2}{*}{$\begin{array}{l}\text { Institution cost (per } \\
\text { year) }\end{array}$} & 0.000186 & 2.07E-06 & $-2.34 \mathrm{e}-06^{*}$ & $1.20 \mathrm{E}-06$ & 0.000177 & 2.07E-06 & $-1.96 \mathrm{E}-06$ & $1.20 \mathrm{E}-06$ \\
\hline & {$[0.000169]$} & [1.94e-06] & [1.26e-06] & {$[1.75 \mathrm{e}-06]$} & {$[0.000171]$} & {$[1.94 \mathrm{e}-06]$} & [1.29e-06] & {$[1.75 \mathrm{e}-06]$} \\
\hline \multirow[t]{2}{*}{$\begin{array}{l}\text { Number of family } \\
\text { members in college }\end{array}$} & -0.306 & -0.00517 & 0.00144 & 0.011 & -0.324 & -0.00517 & 0.00142 & 0.011 \\
\hline & {$[0.784]$} & {$[0.00887]$} & {$[0.00587]$} & {$[0.00816]$} & {$[0.771]$} & {$[0.00887]$} & {$[0.00587]$} & {$[0.00816]$} \\
\hline \multirow[t]{2}{*}{ Private institution } & 3.658 & -0.0223 & $-0.103^{* * *}$ & -0.00774 & 3.053 & -0.0223 & $-0.105 * * *$ & -0.00774 \\
\hline & {$[2.524]$} & {$[0.0291]$} & {$[0.0190]$} & {$[0.0263]$} & [2.919] & {$[0.0291]$} & {$[0.0207]$} & {$[0.0263]$} \\
\hline \multirow[t]{2}{*}{ Constant } & $190.5^{* * *}$ & $0.625^{* * *}$ & $0.749 * * *$ & -0.0203 & $190.1^{* * *}$ & $0.625 * * *$ & $0.741^{* * *}$ & -0.0203 \\
\hline & [15.95] & [0.179] & [0.118] & {$[0.166]$} & [16.06] & [0.179] & {$[0.120]$} & [0.166] \\
\hline Observations & 2,285 & 1,836 & 2,024 & 2,327 & 2,285 & 1,836 & 2,024 & 2,327 \\
\hline R-squared & 0.187 & 0.017 & 0.049 & 0.031 & & & & \\
\hline Number of institutions & & & & & 395 & 371 & 387 & 406 \\
\hline
\end{tabular}

Standard errors in brackets. ${ }^{* * *} \mathrm{p}<0.01,{ }^{* *} \mathrm{p}<0.05,{ }^{*} \mathrm{p}<0.1$

The models also control for mother's and father's education levels. 
Table 5. Effect of financial aid by type of colleges

\begin{tabular}{|c|c|c|c|c|c|c|c|c|}
\hline & \multicolumn{4}{|c|}{ Private colleges } & \multicolumn{4}{|c|}{ Public colleges } \\
\hline & (1) & (2) & (3) & (4) & (5) & (6) & (7) & (8) \\
\hline & GPA & $\begin{array}{l}\text { Willingness } \\
\text { to enroll }\end{array}$ & $\begin{array}{l}\text { Satisfaction } \\
\text { in } 2003\end{array}$ & $\begin{array}{l}\text { Voluntary } \\
\text { work }\end{array}$ & GPA & $\begin{array}{l}\text { Willingness } \\
\text { to enroll }\end{array}$ & $\begin{array}{l}\text { Satisfaction } \\
\text { in } 2003\end{array}$ & $\begin{array}{l}\text { Voluntary } \\
\text { work }\end{array}$ \\
\hline \multirow[t]{2}{*}{ Received any grant } & $8.537 *$ & 0.0429 & 0.0317 & 0.0658 & $15.05^{* * *}$ & -0.00749 & 0.0206 & 0.0437 \\
\hline & {$[4.770]$} & {$[0.0566]$} & {$[0.0466]$} & {$[0.0522]$} & [3.577] & {$[0.0408]$} & {$[0.0214]$} & {$[0.0366]$} \\
\hline \multirow[t]{2}{*}{ Received any loan } & 0.578 & 0.0281 & -0.0406 & $-0.105^{* *}$ & $-12.56 * * *$ & -0.00855 & -0.0164 & -0.0595 \\
\hline & [4.667] & {$[0.0550]$} & {$[0.0467]$} & {$[0.0515]$} & [4.065] & {$[0.0456]$} & {$[0.0244]$} & {$[0.0416]$} \\
\hline \multirow[t]{2}{*}{$\begin{array}{l}\text { Received any work- } \\
\text { study }\end{array}$} & -3.331 & 0.0386 & -0.00332 & 0.0696 & -1.693 & -0.00899 & -0.0527 & 0.0434 \\
\hline & {$[4.480]$} & {$[0.0494]$} & {$[0.0441]$} & {$[0.0491]$} & [5.633] & {$[0.0628]$} & [0.0338] & {$[0.0580]$} \\
\hline \multirow[t]{2}{*}{ SAT/ACT score } & $0.0810^{* * *}$ & 7.34E-05 & $-1.38 \mathrm{E}-05$ & 0.000175 & $0.0741^{* * *}$ & 0.000102 & $2.97 \mathrm{E}-05$ & $0.000174^{* *}$ \\
\hline & [0.0101] & [0.000111] & [9.80e-05] & [0.000108] & [0.00755] & [8.66e-05] & [4.48e-05] & [7.67e-05] \\
\hline \multirow[t]{2}{*}{ Female } & $18.62 * * *$ & -0.00921 & $-0.0608 * *$ & $0.0742 * *$ & $22.10 * * *$ & 0.027 & 0.0179 & $0.0705^{* * *}$ \\
\hline & {$[3.013]$} & {$[0.0345]$} & {$[0.0297]$} & {$[0.0330]$} & {$[2.452]$} & {$[0.0283]$} & {$[0.0146]$} & {$[0.0251]$} \\
\hline \multirow[t]{2}{*}{ Age } & $0.944^{* *}$ & 0.00293 & $0.0107 * *$ & $0.00797^{*}$ & -0.037 & -0.0035 & -0.00256 & $0.0101^{* *}$ \\
\hline & {$[0.426]$} & {$[0.00502]$} & {$[0.00419]$} & {$[0.00479]$} & {$[0.416]$} & [0.00473] & {$[0.00238]$} & {$[0.00416]$} \\
\hline \multirow[t]{2}{*}{ Black } & $-25.63 * * *$ & 0.103 & 0.0087 & 0.123 & $-35.23 * * *$ & $0.149 * *$ & -0.0121 & 0.0658 \\
\hline & [7.254] & {$[0.0725]$} & {$[0.0669]$} & {$[0.0760]$} & {$[6.151]$} & {$[0.0658]$} & {$[0.0384]$} & {$[0.0631]$} \\
\hline \multirow[t]{2}{*}{ Hisp } & -11.2 & $0.128 *$ & 0.0168 & $-0.163^{* *}$ & $-11.87^{* *}$ & $0.145 * *$ & -0.0227 & -0.0171 \\
\hline & {$[7.116]$} & {$[0.0719]$} & {$[0.0652]$} & {$[0.0722]$} & {$[5.902]$} & {$[0.0711]$} & {$[0.0363]$} & {$[0.0605]$} \\
\hline \multirow[t]{2}{*}{ Asian } & -3.494 & -0.0523 & -0.0862 & 0.0286 & $-8.231^{*}$ & 0.0128 & 0.00578 & -0.0516 \\
\hline & {$[6.846]$} & {$[0.0775]$} & {$[0.0740]$} & {$[0.0762]$} & {$[4.670]$} & {$[0.0534]$} & {$[0.0295]$} & {$[0.0482]$} \\
\hline \multirow[t]{2}{*}{ Marital status in 1993} & $30.20 * * *$ & -0.0648 & -0.00413 & 0.0059 & $15.28 * * *$ & -0.0152 & 0.0253 & $0.0992 * *$ \\
\hline & [7.166] & [0.0858] & [0.0692] & [0.0782] & [4.460] & [0.0517] & [0.0263] & {$[0.0456]$} \\
\hline \multirow{2}{*}{$\begin{array}{l}\text { Log of household } \\
\text { income }\end{array}$} & -1.013 & 0.0161 & 0.00747 & $-0.0284 *$ & $2.364^{* *}$ & -0.0111 & $0.0143^{* *}$ & 0.0134 \\
\hline & {$[1.440]$} & {$[0.0161]$} & {$[0.0142]$} & {$[0.0159]$} & {$[1.193]$} & {$[0.0137]$} & {$[0.00717]$} & [0.0123] \\
\hline \multirow[t]{2}{*}{ Selectivity } & -0.545 & -0.0116 & -0.002 & -0.00837 & -0.0815 & 0.00071 & -0.00321 & $-0.0171^{* *}$ \\
\hline & [1.226] & {$[0.0105]$} & {$[0.00904]$} & {$[0.0102]$} & {$[0.776]$} & [0.00887] & [0.00533] & {$[0.00794]$} \\
\hline \multicolumn{9}{|l|}{$\begin{array}{l}\text { Institution cost (per } \\
\text { year) }\end{array}$} \\
\hline & 0.000371 & $5.28 \mathrm{E}-07$ & $-2.69 E-06$ & $-6.54 \mathrm{E}-07$ & 0.000194 & $2.90 \mathrm{E}-06$ & -1.51E-07 & 3.70E-06 \\
\hline & {$[0.000235]$} & [2.70e-06] & [2.23e-06] & [2.50e-06] & {$[0.000254]$} & {$[2.94 \mathrm{e}-06]$} & [1.55e-06] & [2.60e-06] \\
\hline \multirow{4}{*}{$\begin{array}{l}\text { Number of family } \\
\text { members in college } \\
\text { Constant }\end{array}$} & -1.293 & -0.0175 & 0.0122 & 0.00832 & 0.0503 & 0.00136 & -0.00596 & 0.0133 \\
\hline & [1.206] & {$[0.0140]$} & {$[0.0122]$} & {$[0.0134]$} & [1.019] & {$[0.0116]$} & [0.00603] & [0.0104] \\
\hline & $184.2 * * *$ & $0.476^{*}$ & $0.452 *$ & 0.258 & $199.1 * * *$ & $0.778 * * *$ & $0.858 * * *$ & -0.234 \\
\hline & [26.03] & [0.287] & [0.251] & [0.280] & [20.89] & [0.237] & [0.123] & [0.211] \\
\hline Observations & 817 & 698 & 740 & 858 & 1,468 & 1,138 & 1,284 & 1,469 \\
\hline Number of institutions & 198 & 184 & 197 & 207 & 197 & 187 & 190 & 199 \\
\hline
\end{tabular}

Standard errors in brackets

*** $\mathrm{p}<0.01, * * \mathrm{p}<0.05,{ }^{*} \mathrm{p}<0.1$

The models also control for mother's and father's

education levels. 
Table 6. Effect of financial aid with sample restrictions on overall GPA

\begin{tabular}{|c|c|c|c|c|c|c|c|c|c|c|}
\hline & (1) & $(2)$ & (3) & (4) & (5) & (6) & $(7)$ & $(8)$ & (9) & $(10)$ \\
\hline & Middle 35\% & Middle 30\% & Middle 25\% & Middle 20\% & Middle 10\% & $\begin{array}{l}\text { (1) minus } \\
\text { middle 5\% }\end{array}$ & $\begin{array}{l}(2) \text { minus } \\
\text { middle } 5 \%\end{array}$ & $\begin{array}{l}(3) \text { minus } \\
\text { middle } 5 \% \\
\end{array}$ & $\begin{array}{l}(4) \text { minus } \\
\text { middle } 5 \% \\
\end{array}$ & $\begin{array}{c}\text { (5) -mid } \\
5 \% \\
\end{array}$ \\
\hline Received any grant & $\begin{array}{c}13.87 * * * \\
{[4.946]}\end{array}$ & $\begin{array}{c}14.13^{* * *} \\
{[5.255]}\end{array}$ & $\begin{array}{c}17.91^{* * *} \\
{[5.736]}\end{array}$ & $\begin{array}{c}23.18^{* * *} \\
{[6.325]}\end{array}$ & $\begin{array}{c}15.23 \\
{[9.714]}\end{array}$ & $\begin{array}{c}15.30 * * * \\
{[5.368]}\end{array}$ & $\begin{array}{c}16.36 * * * \\
{[5.768]}\end{array}$ & $\begin{array}{c}21.38 * * * \\
{[6.428]}\end{array}$ & $\begin{array}{c}29.12 * * * \\
{[7.264]}\end{array}$ & $\begin{array}{c}20.54 \\
{[14.91]}\end{array}$ \\
\hline Received any loan & $\begin{array}{l}-8.269 \\
{[5.184]}\end{array}$ & $\begin{array}{l}-7.457 \\
{[5.530]}\end{array}$ & $\begin{array}{l}-10.30^{*} \\
{[6.135]}\end{array}$ & $\begin{array}{c}-17.62 * * * \\
{[6.714]}\end{array}$ & $\begin{array}{l}-10.83 \\
{[10.45]}\end{array}$ & $\begin{array}{c}-6.52 \\
{[5.666]}\end{array}$ & $\begin{array}{l}-5.709 \\
{[6.114]}\end{array}$ & $\begin{array}{l}-8.898 \\
{[6.962]}\end{array}$ & $\begin{array}{c}-16.86^{* *} \\
{[7.805]}\end{array}$ & $\begin{array}{c}5.107 \\
{[16.53]}\end{array}$ \\
\hline Received any work-study & $\begin{array}{l}-1.707 \\
{[6.101]}\end{array}$ & $\begin{array}{l}-0.734 \\
{[6.465]}\end{array}$ & $\begin{array}{c}1.026 \\
{[7.358]}\end{array}$ & $\begin{array}{c}-7.394 \\
{[8.346]}\end{array}$ & $\begin{array}{l}-4.489 \\
{[13.99]}\end{array}$ & $\begin{array}{c}-0.51 \\
{[6.672]}\end{array}$ & $\begin{array}{c}0.225 \\
{[7.165]}\end{array}$ & $\begin{array}{c}3.59 \\
{[8.439]}\end{array}$ & $\begin{array}{l}-7.409 \\
{[9.998]}\end{array}$ & $\begin{array}{c}-21.98 \\
{[28.56]}\end{array}$ \\
\hline SAT/ACT score & $\begin{array}{c}0.0769 * * * \\
{[0.0106]}\end{array}$ & $\begin{array}{c}0.0758 * * * \\
{[0.0115]}\end{array}$ & $\begin{array}{c}0.0622 * * * \\
{[0.0130]}\end{array}$ & $\begin{array}{c}0.0574 * * * \\
{[0.0142]}\end{array}$ & $\begin{array}{c}0.0495 * * \\
{[0.0221]}\end{array}$ & $\begin{array}{c}0.0911 * * * \\
{[0.0115]}\end{array}$ & $\begin{array}{c}0.0925^{* * *} \\
{[0.0127]}\end{array}$ & $\begin{array}{c}0.0829 * * * \\
{[0.0148]}\end{array}$ & $\begin{array}{c}0.0874 * * * \\
{[0.0166]}\end{array}$ & $\begin{array}{c}0.123^{* * *} \\
{[0.0362]}\end{array}$ \\
\hline Female & $\begin{array}{c}22.45 * * * \\
{[3.294]}\end{array}$ & $\begin{array}{c}20.98 * * * \\
{[3.536]}\end{array}$ & $\begin{array}{c}18.75^{* * *} \\
{[3.914]}\end{array}$ & $\begin{array}{c}15.13 * * * \\
{[4.353]}\end{array}$ & $\begin{array}{c}8.921 \\
{[6.708]}\end{array}$ & $\begin{array}{c}23.92 * * * \\
{[3.550]}\end{array}$ & $\begin{array}{c}22.22 * * * \\
{[3.839]}\end{array}$ & $\begin{array}{c}20.43 * * * \\
{[4.352]}\end{array}$ & $\begin{array}{c}17.58 * * * \\
{[5.047]}\end{array}$ & $\begin{array}{c}15.89 \\
{[9.987]}\end{array}$ \\
\hline Age & $\begin{array}{l}0.808^{*} \\
{[0.476]}\end{array}$ & $\begin{array}{c}0.7 \\
{[0.504]}\end{array}$ & $\begin{array}{l}0.952^{*} \\
{[0.535]}\end{array}$ & $\begin{array}{l}1.029 * \\
{[0.579]}\end{array}$ & $\begin{array}{c}1.276 \\
{[1.464]}\end{array}$ & $\begin{array}{c}0.721 \\
{[0.491]}\end{array}$ & $\begin{array}{c}0.531 \\
{[0.523]}\end{array}$ & $\begin{array}{c}0.822 \\
{[0.560]}\end{array}$ & $\begin{array}{c}0.816 \\
{[0.606]}\end{array}$ & $\begin{array}{c}2.721 \\
{[2.107]}\end{array}$ \\
\hline Black & $-22.78 * * *$ & $-22.79 * *$ & $-20.99 * *$ & $-23.65 * *$ & $-34.70^{*}$ & $-20.66^{* *}$ & $-21.31^{* *}$ & $-19.16^{*}$ & -18.57 & 10.09 \\
\hline Hisp & $\begin{array}{c}{[8.617]} \\
-22.32 * * *\end{array}$ & $\begin{array}{c}{[8.917]} \\
-23.79 * * *\end{array}$ & $\begin{array}{c}{[9.953]} \\
-22.74 * *\end{array}$ & $\begin{array}{l}{[11.68]} \\
-17.12\end{array}$ & $\begin{array}{l}{[17.86]} \\
-27.63^{*}\end{array}$ & $\begin{array}{c}{[9.582]} \\
-22.93^{* *}\end{array}$ & $\begin{array}{c}{[9.965]} \\
-25.43 * * *\end{array}$ & $\begin{array}{c}{[11.49]} \\
-26.22 * *\end{array}$ & $\begin{array}{l}{[14.67]} \\
-17.55\end{array}$ & $\begin{array}{c}{[42.62]} \\
-40.37\end{array}$ \\
\hline Asian & $\begin{array}{l}{[8.389]} \\
-1.459 \\
{[7.169]}\end{array}$ & $\begin{array}{l}{[8.790]} \\
-4.417 \\
{[7.772]}\end{array}$ & $\begin{array}{l}{[9.495]} \\
-1.276 \\
{[8.499]}\end{array}$ & $\begin{array}{c}{[10.47]} \\
2.489 \\
{[8.844]}\end{array}$ & $\begin{array}{c}{[16.62]} \\
7.623 \\
{[12.80]}\end{array}$ & $\begin{array}{l}{[9.010]} \\
-3.465 \\
{[7.943]}\end{array}$ & $\begin{array}{c}{[9.535]} \\
-7.509 \\
{[8.768]}\end{array}$ & $\begin{array}{l}{[10.48]} \\
-4.481 \\
{[9.820]}\end{array}$ & $\begin{array}{c}{[11.64]} \\
-0.41 \\
{[10.37]}\end{array}$ & $\begin{array}{c}{[24.77]} \\
7.221 \\
{[19.69]}\end{array}$ \\
\hline Marital status in 1993 & $15.58 * * *$ & $15.67^{* *}$ & $16.44^{* *}$ & 7.874 & 1.226 & $16.92^{* * *}$ & $17.83^{* * *}$ & $20.49 * * *$ & 11.94 & 13.74 \\
\hline $\begin{array}{l}\text { Log of household income } \\
\text { Selectivity }\end{array}$ & $\begin{array}{c}{[5.898]} \\
-8.644^{* *} \\
{[4.408]} \\
-0.335\end{array}$ & $\begin{array}{c}{[6.322]} \\
-11.44^{* *} \\
{[5.211]} \\
-0.899\end{array}$ & $\begin{array}{c}{[7.080]} \\
-10.63 \\
{[6.470]} \\
-0.971\end{array}$ & $\begin{array}{c}{[8.511]} \\
-15.72^{*} \\
{[8.712]} \\
-1.355\end{array}$ & $\begin{array}{c}{[13.21]} \\
8.701 \\
{[24.07]} \\
-3.557\end{array}$ & $\begin{array}{c}{[6.273]} \\
-8.459^{*} \\
{[4.552]} \\
0.382\end{array}$ & $\begin{array}{c}{[6.803]} \\
-11.29 * * \\
{[5.396]} \\
-0.103\end{array}$ & $\begin{array}{c}{[7.792]} \\
-11.10^{*} \\
{[6.724]} \\
0.0758\end{array}$ & $\begin{array}{c}{[9.709]} \\
-16.68^{*} \\
{[9.101]} \\
-0.103\end{array}$ & $\begin{array}{c}{[20.15]} \\
4.662 \\
{[28.44]} \\
-1.792\end{array}$ \\
\hline Institution cost (per year) & $\begin{array}{c}{[1.080]} \\
0.000627^{* *}\end{array}$ & $\begin{array}{c}{[1.097]} \\
0.000705^{* *}\end{array}$ & $\begin{array}{c}{[1.199]} \\
0.000949^{* * *}\end{array}$ & $\begin{array}{c}{[1.436]} \\
0.000868 * *\end{array}$ & $\begin{array}{c}{[2.196]} \\
0.000515\end{array}$ & $\begin{array}{c}{[1.180]} \\
0.000624^{* *}\end{array}$ & $\begin{array}{c}{[1.251]} \\
0.000696 * *\end{array}$ & $\begin{array}{c}{[1.407]} \\
0.00102^{* * *}\end{array}$ & $\begin{array}{c}{[1.587]} \\
0.000856^{* *}\end{array}$ & $\begin{array}{c}{[3.302]} \\
-0.000346\end{array}$ \\
\hline Number of family & $\begin{array}{c}{[0.000288]} \\
1.92\end{array}$ & $\begin{array}{c}{[0.000306]} \\
1.71\end{array}$ & $\begin{array}{c}{[0.000346]} \\
1.315\end{array}$ & $\begin{array}{c}{[0.000373]} \\
1.639\end{array}$ & $\begin{array}{c}{[0.000620]} \\
6.254^{*}\end{array}$ & $\begin{array}{c}{[0.000307]} \\
1.216\end{array}$ & $\begin{array}{c}{[0.000331]} \\
0.826\end{array}$ & $\begin{array}{c}{[0.000382]} \\
0.498\end{array}$ & $\begin{array}{c}{[0.000421]} \\
-0.253\end{array}$ & $\begin{array}{c}{[0.00101]} \\
2.061\end{array}$ \\
\hline $\begin{array}{l}\text { members in college } \\
\text { Private institution }\end{array}$ & $\begin{array}{l}{[1.418]} \\
15.31^{* *}\end{array}$ & $\begin{array}{l}{[1.531]} \\
20.76^{* *}\end{array}$ & $\begin{array}{c}{[1.809]} \\
18.11\end{array}$ & $\begin{array}{l}{[2.115]} \\
26.86^{*}\end{array}$ & $\begin{array}{c}{[3.563]} \\
-6.523\end{array}$ & $\begin{array}{l}{[1.494]} \\
13.12 *\end{array}$ & $\begin{array}{l}{[1.623]} \\
18.11^{* *}\end{array}$ & $\begin{array}{c}{[1.973]} \\
14.76\end{array}$ & $\begin{array}{c}{[2.411]} \\
25.27\end{array}$ & $\begin{array}{c}{[5.482]} \\
1.025\end{array}$ \\
\hline & {$[7.600]$} & {$[8.950]$} & [11.04] & [15.33] & [42.89] & [7.739] & [9.155] & [11.30] & {$[15.76]$} & [51.65] \\
\hline Constant & $\begin{array}{c}256.6^{* * *} \\
{[48.81]} \\
\end{array}$ & $\begin{array}{c}300.2^{* * *} \\
{[55.71]} \\
\end{array}$ & $\begin{array}{c}297.3 * * * \\
{[67.23]} \\
\end{array}$ & $\begin{array}{c}348.8^{* * *} \\
{[86.96]} \\
\end{array}$ & $\begin{array}{c}110.7 \\
{[232.2]}\end{array}$ & $\begin{array}{c}245.9^{* * *} \\
{[50.87]} \\
\end{array}$ & $\begin{array}{c}292.4^{* * *} \\
{[58.23]} \\
\end{array}$ & $\begin{array}{c}288.4^{* * *} \\
{[70.58]} \\
\end{array}$ & $\begin{array}{c}341.4 * * * \\
{[91.68]} \\
\end{array}$ & $\begin{array}{c}93.98 \\
{[281.4]}\end{array}$ \\
\hline $\begin{array}{l}\text { Observations } \\
\text { Number of institutions }\end{array}$ & $\begin{array}{l}779 \\
273\end{array}$ & $\begin{array}{l}689 \\
255\end{array}$ & $\begin{array}{l}580 \\
235\end{array}$ & $\begin{array}{l}446 \\
201\end{array}$ & $\begin{array}{l}225 \\
129\end{array}$ & $\begin{array}{l}670 \\
263\end{array}$ & $\begin{array}{l}580 \\
243\end{array}$ & $\begin{array}{l}471 \\
223\end{array}$ & $\begin{array}{l}337 \\
179\end{array}$ & $\begin{array}{c}116 \\
84\end{array}$ \\
\hline
\end{tabular}

Standard errors in brackets

*** $\mathrm{p}<0.01,{ }^{* *} \mathrm{p}<0.05, * \mathrm{p}<0.1$

The models also control for mother's and father's education

levels. 
Table 7. The effect of receiving grant on academic and non-academic outcomes: Using instrumental variable

\begin{tabular}{|c|c|c|c|c|c|c|c|c|}
\hline \multirow[b]{2}{*}{ Dependent variable } & \multicolumn{2}{|c|}{ GPA } & \multicolumn{2}{|c|}{ Willingness to enroll } & \multicolumn{2}{|c|}{ Satisfaction in 2003} & \multicolumn{2}{|c|}{ Voluntary work } \\
\hline & $\begin{array}{c}\text { 1st stge } \\
\text { Received } \\
\text { any grant }\end{array}$ & $\begin{array}{c}\text { 2nd stage } \\
\text { GPA }\end{array}$ & $\begin{array}{l}\text { 1st stage } \\
\text { Received } \\
\text { any grant }\end{array}$ & $\begin{array}{c}\text { 2nd stage } \\
\text { Willingness } \\
\text { to enroll }\end{array}$ & $\begin{array}{l}\text { 1st stage } \\
\text { Received } \\
\text { any grant }\end{array}$ & $\begin{array}{c}\text { 2nd stage } \\
\text { Satisfaction } \\
\text { in } 2003\end{array}$ & $\begin{array}{l}\text { 1st stage } \\
\text { Received } \\
\text { any grant }\end{array}$ & $\begin{array}{l}\text { 2nd stage } \\
\text { Voluntary } \\
\text { work }\end{array}$ \\
\hline Received any grant & & $\begin{array}{c}22.28 * * * \\
{[2.919]}\end{array}$ & & $\begin{array}{c}0.0318 \\
{[0.0328]}\end{array}$ & & $\begin{array}{c}0.0343 \\
{[0.0216]}\end{array}$ & & $\begin{array}{c}0.0645^{* *} \\
{[0.0301]}\end{array}$ \\
\hline $\begin{array}{l}\text { Applied for financial } \\
\text { aid }\end{array}$ & $\begin{array}{c}0.696 * * * \\
{[0.0121]}\end{array}$ & & $\begin{array}{c}0.701^{* * *} \\
{[0.0137]}\end{array}$ & & $\begin{array}{c}0.694^{* * *} \\
{[0.0130]}\end{array}$ & & $\begin{array}{c}0.696 * * * \\
{[0.0121]}\end{array}$ & \\
\hline SAT/ACT score & $\begin{array}{c}-2.62 \mathrm{E}-05 \\
{[3.60 \mathrm{e}-05]}\end{array}$ & $\begin{array}{c}0.0740 * * * \\
{[0.00602]}\end{array}$ & $\begin{array}{c}-8.94 \mathrm{E}-06 \\
{[4.00 \mathrm{e}-05]}\end{array}$ & $\begin{array}{c}8.23 \mathrm{E}-05 \\
{[6.71 \mathrm{e}-05]}\end{array}$ & $\begin{array}{c}-9.41 \mathrm{E}-06 \\
{[3.85 \mathrm{e}-05]}\end{array}$ & $\begin{array}{c}-3.55 \mathrm{E}-06 \\
{[4.43 \mathrm{e}-05]}\end{array}$ & $\begin{array}{c}-2.61 \mathrm{E}-05 \\
{[3.57 \mathrm{e}-05]}\end{array}$ & $\begin{array}{c}0.000169 * * * \\
{[6.18 \mathrm{e}-05]}\end{array}$ \\
\hline Female & $\begin{array}{c}0.0219 * \\
{[0.0114]}\end{array}$ & $\begin{array}{c}20.81^{* * *} \\
{[1.912]}\end{array}$ & $\begin{array}{c}0.0334 * * * \\
{[0.0129]}\end{array}$ & $\begin{array}{c}0.0112 \\
{[0.0216]}\end{array}$ & $\begin{array}{c}0.0228 * \\
{[0.0123]}\end{array}$ & $\begin{array}{c}-0.0138 \\
{[0.0141]}\end{array}$ & $\begin{array}{c}0.0204 * \\
{[0.0114]}\end{array}$ & $\begin{array}{c}0.0700^{* * *} \\
{[0.0197]}\end{array}$ \\
\hline Age & $\begin{array}{c}-0.00181 \\
{[0.00179]}\end{array}$ & $\begin{array}{c}0.412 \\
{[0.300]}\end{array}$ & $\begin{array}{c}-0.0018 \\
{[0.00201]}\end{array}$ & $\begin{array}{l}-0.000133 \\
{[0.00338]}\end{array}$ & $\begin{array}{c}-0.00181 \\
{[0.00187]}\end{array}$ & $\begin{array}{c}0.00291 \\
{[0.00215]}\end{array}$ & $\begin{array}{c}-0.0024 \\
{[0.00178]}\end{array}$ & $\begin{array}{c}0.00778^{* *} \\
{[0.00308]}\end{array}$ \\
\hline Black & $\begin{array}{c}0.0406 \\
{[0.0276]}\end{array}$ & $\begin{array}{c}-33.54 * * * \\
{[4.634]}\end{array}$ & $\begin{array}{c}0.0457 \\
{[0.0286]}\end{array}$ & $\begin{array}{c}0.124 * * * \\
{[0.0482]}\end{array}$ & $\begin{array}{c}0.0487 \\
{[0.0301]}\end{array}$ & $\begin{array}{l}-0.00529 \\
{[0.0348]}\end{array}$ & $\begin{array}{c}0.0432 \\
{[0.0276]}\end{array}$ & $\begin{array}{c}0.0836 * \\
{[0.0479]}\end{array}$ \\
\hline Hisp & $\begin{array}{c}-0.018 \\
{[0.0266]}\end{array}$ & $\begin{array}{c}-13.74 * * * \\
{[4.451]}\end{array}$ & $\begin{array}{c}-0.0032 \\
{[0.0296]}\end{array}$ & $\begin{array}{c}0.126^{* *} \\
{[0.0497]}\end{array}$ & $\begin{array}{c}-0.00784 \\
{[0.0289]}\end{array}$ & $\begin{array}{l}-0.00701 \\
{[0.0333]}\end{array}$ & $\begin{array}{c}-0.0188 \\
{[0.0264]}\end{array}$ & $\begin{array}{c}-0.0688 \\
{[0.0457]}\end{array}$ \\
\hline Asian & $\begin{array}{l}-0.00485 \\
{[0.0232]}\end{array}$ & $\begin{array}{l}-6.466^{*} \\
{[3.872]}\end{array}$ & $\begin{array}{c}0.0118 \\
{[0.0258]}\end{array}$ & $\begin{array}{l}-0.0118 \\
{[0.0432]}\end{array}$ & $\begin{array}{c}0.0101 \\
{[0.0261]}\end{array}$ & $\begin{array}{c}-0.00944 \\
{[0.0301]}\end{array}$ & $\begin{array}{l}-0.00565 \\
{[0.0233]}\end{array}$ & $\begin{array}{c}-0.0291 \\
{[0.0404]}\end{array}$ \\
\hline $\begin{array}{l}\text { Marital status in } \\
1993\end{array}$ & $\begin{array}{c}0.0626 * * * \\
{[0.0223]}\end{array}$ & $\begin{array}{c}17.87 * * * \\
{[3.734]}\end{array}$ & $\begin{array}{c}0.0492 * \\
{[0.0256]}\end{array}$ & $\begin{array}{c}-0.038 \\
{[0.0431]}\end{array}$ & $\begin{array}{c}0.0597^{* *} \\
{[0.0236]}\end{array}$ & $\begin{array}{c}0.0205 \\
{[0.0272]}\end{array}$ & $\begin{array}{c}0.0612 * * * \\
{[0.0223]}\end{array}$ & $\begin{array}{c}0.0860 * * \\
{[0.0387]}\end{array}$ \\
\hline $\begin{array}{l}\text { Log of household } \\
\text { income }\end{array}$ & $\begin{array}{c}- \\
0.0644^{* * *} \\
{[0.00543]}\end{array}$ & $\begin{array}{c}3.519 * * * \\
{[0.971]}\end{array}$ & $\begin{array}{c}- \\
0.0638^{* * *} \\
{[0.00604]}\end{array}$ & $\begin{array}{c}0.00371 \\
{[0.0109]}\end{array}$ & $\begin{array}{c}- \\
0.0675^{* * *} \\
{[0.00586]}\end{array}$ & $\begin{array}{c}0.0177 * * \\
{[0.00726]}\end{array}$ & $\begin{array}{c}- \\
0.0652^{* * *} \\
{[0.00546]}\end{array}$ & $\begin{array}{c}0.00607 \\
{[0.0101]}\end{array}$ \\
\hline Selectivity & $\begin{array}{c}0.0101^{* * *} \\
{[0.00354]}\end{array}$ & $\begin{array}{c}-0.319 \\
{[0.593]}\end{array}$ & $\begin{array}{l}0.0107 * * * \\
{[0.00392]}\end{array}$ & $\begin{array}{l}-0.00688 \\
{[0.00659]}\end{array}$ & $\begin{array}{l}0.0104 * * * \\
{[0.00378]}\end{array}$ & $\begin{array}{l}-0.00189 \\
{[0.00436]}\end{array}$ & $\begin{array}{l}0.0115 * * * \\
{[0.00353]}\end{array}$ & $\begin{array}{l}-0.0122 * * \\
{[0.00612]}\end{array}$ \\
\hline $\begin{array}{l}\text { Institution cost (per } \\
\text { year) }\end{array}$ & $\begin{array}{c}2.90 \mathrm{e}- \\
06^{* * *} \\
{[1.00 \mathrm{e}-06]}\end{array}$ & $\begin{array}{c}6.08 \mathrm{E}-05 \\
{[0.000169]}\end{array}$ & $\begin{array}{c}2.74 \mathrm{e}- \\
06^{* *} \\
{[1.14 \mathrm{e}-06]}\end{array}$ & $\begin{array}{c}2.21 \mathrm{E}-06 \\
{[1.92 \mathrm{e}-06]}\end{array}$ & $\begin{array}{l}1.94 \mathrm{e}-06^{*} \\
{[1.08 \mathrm{e}-06]}\end{array}$ & $\begin{array}{c}-2.65 \mathrm{e}- \\
06^{* *} \\
{[1.25 \mathrm{e}-06]}\end{array}$ & $\begin{array}{c}2.66 \mathrm{e}- \\
06 * * * \\
{[9.98 \mathrm{e}-07]}\end{array}$ & $\begin{array}{c}5.93 \mathrm{E}-07 \\
{[1.74 \mathrm{e}-06]}\end{array}$ \\
\hline $\begin{array}{l}\text { Number of family } \\
\text { members in college }\end{array}$ & $\begin{array}{c}0.00687 \\
{[0.00471]}\end{array}$ & $\begin{array}{l}-0.586 \\
{[0.789]}\end{array}$ & $\begin{array}{c}0.00793 \\
{[0.00525]}\end{array}$ & $\begin{array}{l}-0.00509 \\
{[0.00882]}\end{array}$ & $\begin{array}{c}0.00668 \\
{[0.00506]}\end{array}$ & $\begin{array}{l}0.000642 \\
{[0.00584]}\end{array}$ & $\begin{array}{c}0.00624 \\
{[0.00469]}\end{array}$ & $\begin{array}{c}0.0103 \\
{[0.00815]}\end{array}$ \\
\hline Private institution & $\begin{array}{c}0.0706^{* * *} \\
{[0.0151]}\end{array}$ & $\begin{array}{c}0.756 \\
{[2.560]}\end{array}$ & $\begin{array}{c}0.0541 * * * \\
{[0.0172]}\end{array}$ & $\begin{array}{l}-0.0209 \\
{[0.0290]}\end{array}$ & $\begin{array}{c}0.0810 * * * \\
{[0.0163]}\end{array}$ & $\begin{array}{c}-0.111^{* * *} \\
{[0.0191]}\end{array}$ & $\begin{array}{c}0.0728 * * * \\
{[0.0151]}\end{array}$ & $\begin{array}{l}-0.0163 \\
{[0.0265]}\end{array}$ \\
\hline Constant & $\begin{array}{c}0.707 * * * \\
{[0.0950]}\end{array}$ & $\begin{array}{c}167.5^{* * *} \\
{[16.32]}\end{array}$ & $\begin{array}{c}0.680^{* * *} \\
{[0.105]}\end{array}$ & $\begin{array}{c}0.620^{* * *} \\
{[0.182]}\end{array}$ & $\begin{array}{c}0.708^{* * *} \\
{[0.101]}\end{array}$ & $\begin{array}{c}0.698^{* * *} \\
{[0.120]}\end{array}$ & $\begin{array}{c}0.729 * * * \\
{[0.0944]}\end{array}$ & $\begin{array}{c}-0.106 \\
{[0.168]}\end{array}$ \\
\hline Observations & 2,285 & 2,285 & 1,836 & 1,836 & 2,024 & 2,024 & 2,327 & 2,327 \\
\hline R-squared & 0.681 & 0.169 & 0.685 & 0.017 & 0.678 & 0.049 & 0.678 & 0.026 \\
\hline IV F-stat & & 3285 & & 2621 & & 2847 & & 3316 \\
\hline Durbin pval & & 0 & & 0.659 & & 0.368 & & 0.0018 \\
\hline
\end{tabular}

Standard errors in parentheses

${ }^{* * *} \mathrm{p}<0.01,{ }^{* *} \mathrm{p}<0.05,{ }^{*} \mathrm{p}<0.1$

The models also control for mother's and father's education levels. 


\section{APPENDIX A: MERIT AID}

Merit-based financial aid includes athletic scholarships, assistance from the military such as Reserve Officer Training Corps, and aid based on academic abilities, which is the concern here. The first substantial discussion of merit-based financial aid based on academic ability that appears in the EBSCO publications database was in 1990 (Hauptman 1990). The largest such program operating in the period we examine was the New York State Regents Scholarship program, which limited aid to those without financial need to $\$ 300$ per year in the period we examine and was only applicable to New York State residents who also attended a college in New York State. This program accounted for more than one-third of all the aid that was not need-based in the US during the period we examine. For background on the Regent's program, see

http://www.hesc.ny.gov/content.nsf/CA/Appendix_E_New_Yorks_Tuition_Assistance_Program A_History. The National Association of State Scholarship and Grant Programs $20^{\text {th }}$ Annual Survey Report 1998-1989 finds that \$57 million was spent on merit-based aid and \$18 million of that was the Regents program._The National Merit Scholarship program, which was the only national-level merit aid program, was miniscule compared to the base of college students then and remains that way today: there were roughly 10,000 awards in 2012 against approximately 20 million students in colleges and universities. A review of aid options in 1990 described merit awards as virtually all honorific, good for one’s ego but not much more (Tritch 1990). The Georgia Hope Scholarships, now the largest merit-based aid program, did not begin until 1993, after the students we examined graduated.

The data does include a variable measuring of "merit-based" aid, which includes all forms of aid based on attributes of the student: honorary award received in high school, athletic scholarships, and support from the US military, all of which may be correlated with ability or other attributes that may affect the outcomes we study. 5.4 percent of the students reported receiving an athletic scholarship of some kind, and 2.8 percent report receiving some sort of aid that they believe was based on other forms of merit. Some amount of that latter figure may well reflect an upward social desirability bias in student reporting. 